\title{
Synthesis, molecular structure, and properties of DABCO bromide based ionic liquid combining spectroscopic studies with DFT calculations
}

Bekhaled Fetouhi ${ }^{1,2}$, Boumediene Haddad ${ }^{3,4,}$, Silvia Antonia Brandán ${ }^{5}$, Annalisa Paolone ${ }^{6}$, Didier Villemin ${ }^{4}$, Mostefa Boumediene ${ }^{3}$, Mustapha Rahmouni ${ }^{2}$, Serge Bresson ${ }^{7}$.

${ }^{1}$ Faculty of Natural and Life Sciences, University of Tiaret, BP78 Zaaroura Tiaret 14000, Algeria.

${ }^{2}$ Synthesis and Catalysis Laboratory LSCT, Tiaret University, Tiaret, Algeria.

${ }^{3}$ Chemistry Laboratory of Synthesis, Properties, and Applications (CLSPA-Saida), University of Saida, Algeria.

${ }^{4}$ LCMT, ENSICAEN, UMR 6507 CNRS, University of Caen, 6 bd Ml Juin, 14050 Caen, France

${ }^{5}$ Cátedra de Química General, Instituto de Química Inorgánica, Facultad de Bioquímica. Química y Farmacia, Universidad Nacional de Tucumán, Ayacucho 471, (4000) San Miguel de Tucumán, Tucumán, Argentina. ${ }^{6}$ CNR-ISC, U.O.S. La Sapienza, Piazzale A. Moro 5, 00185 Roma, Italy

${ }^{7}$ Laboratoire de Physique des Systèmes Complexes, Université Picardie Jules Verne, 33 rue St Leu 80039 Amiens cedex, France.

*Corresponding author: Tel.: +213676802567

E-mail : haddadboumediene@yahoo.com (HADDAD Boumediene). 


\begin{abstract}
A new DABCO-based ionic liquid, namely 1-octyl-1,4-diazabicyclo [2.2.2] octan-1-ium Bromide $\left(\left[\mathrm{C}_{8} \mathrm{DABCO}^{+}\right]\left[\mathrm{Br}^{-}\right]\right)$has been synthesized through $\mathrm{N}$-alkylation of 1,4-diazabicyclo [2.2.2] octane with 1-bromooctane using a simple procedure in one step. This $\left[\mathrm{C}_{8} \mathrm{DABCO}{ }^{+}\right]$ [Br-] IL was characterized by FT-IR, FT-Raman and by ${ }^{1} \mathrm{H}$ and ${ }^{13} \mathrm{C}-\mathrm{NMR}$ spectroscopies. The structure of $\left[\mathrm{C}_{8} \mathrm{DABCO}^{+}\right]\left[\mathrm{Br}^{-}\right] \mathrm{IL}$ was confirmed combining ${ }^{1} \mathrm{H}$ and ${ }^{13} \mathrm{C}-\mathrm{NMR}$ spectroscopies with B3LYP/6-31G* calculations. Three ionic $\mathrm{C}-\mathrm{H} \cdots \mathrm{Br}$ bonds were predicted by natural bond orbital (NBO), atoms in molecules (AIM) calculations and bond orders but a monodentate coordination between cation and anion is suggested because only one of them has higher energy and lower distance. The effect of $\mathrm{Br}$ on properties of IL is clearly observed by the change in orientation and direction of dipole moment vector in the IL, as compared with the cation. NBO studies reveal that the $\mathrm{Br}$ anion strongly stabilizes to cation to form the IL. The complete vibrational assignments of 129 and 132 vibration modes expected for the cation and its IL were performed by using two harmonic force fields with the SQMFF methodology and transferable scaling factors. The scaled harmonic force constants were also reported for both species. The $\mathrm{Br}$ confers a higher reactivity to $\left[\mathrm{C}_{8} \mathrm{DABCO}{ }^{+}\right]\left[\mathrm{Br}^{-}\right]$, as suggested by analyses of frontier orbitals. The effect of $\mathrm{Br}$ is also observed in the different assignments observed for the IL and its cation. Reasonable correlations were found between the experimental IR, Raman and NMR spectra and the corresponding theoretical ones.
\end{abstract}

KEYWORDS: 1,4-diazabicyclo[2.2.2]octane, DABCO-ionic liquids; vibrational spectra; IR; Raman measurements; DFT calculations. 


\section{Introduction}

In the last two decades, DABCO-based ionic liquids have generated considerable attention as a new family of solvent media that possesses many important properties [1-23]. Thus, these new type of ionic liquids (ILs) structurally consisting of triethylenediamine group, also known as (1,4-diazabicyclo [2.2.2] octane) cations containing different anions. The interesting of these species are that they have two $\mathrm{N}$ atoms where one of them has three organic substituents and is a tertiary amine while the other one has four organic substituents and, for this reason, it is a quaternary ammonium cation with a charged nitrogen center. The nature of this diazabicyclic DABCO cation as tertiary amine with a cage-like structure and combined anion determines the physical and chemical properties of the formed ionic liquid [1-2]. The properties of DABCO ILs and its derivatives make them a very promising class of materials for a wide range of applications such as, catalysis included a complexing ligand in the Suzu-ki-Miyaura reaction and the Sonogashira coupling, metal absorbents from aqueous solutions, potent antimicrobial and antibacterial agents, gas sorption and separation, optical, building units of excellent molecular ferroelectrics, electronic devices field and in the synthesis of metal-organic frameworks (MOFs) [3-7]. These DABCO materials are facile to prepare from commercially available and relatively inexpensive eco-friendly, high reactive, easy to handle and non-toxic base catalyst for various organic transformations [8]. The chemical reaction of these DABCO with alkyl halides yields transfer of the alkyl group to the DABCO and results in an alkylated DABCO halide -based ionic liquids [9-10]. The possible combinations of DABCO cation with different anions lead to DABCO ILs containing a wide range of physicochemical properties [11-23]. Thus, by synthesis of different types DABCObased ionic liquids was possible to obtain $\mathrm{DABCO}$ molecules with $\mathrm{D}_{3}$ symmetry where the symmetry often change depending on the interatomic interactions of DABCO [14-15]. To perform the vibrational analysis of $\mathrm{DABCO}$ cation is complicated due to the presence of a cage-like structure and, only some vibrational modes were reported for few derivatives [1923]. In recent times, the combination of vibrational spectroscopy with DFT calculations and the use of scaled quantum mechanical force field (SQMFF) methodology have allowed to identify many molecular structures of ionic liquids including some very complex [24-28]. Besides, both techniques combined constitute a very good tactic useful to investigate structural properties and different interactions that take place between cations and anions that compose ionic liquids [29-31].

To the best of our knowledge, the synthesis and vibrational properties of $\left[\mathrm{C}_{8} \mathrm{DABCO}{ }^{+}\right]\left[\mathrm{Br}^{-}\right]$ ionic liquid and its cation are not available in the literature neither the complete vibrational 
assignments of infrared and Raman spectra of alkylated DABCO. Hence, the aims of this work are the structural and vibrational characterizations of $\left[\mathrm{C}_{8} \mathrm{DABCO}^{+}\right]\left[\mathrm{Br}^{-}\right]$by using the experimental IR and FT-Raman spectra and DFT calculations based on the hybrid B3LYP/6$31 \mathrm{G}^{*}$ method [32,33]. Here, two harmonic force fields were employed to perform the complete vibrational assignments of $\left[\mathrm{C}_{8} \mathrm{DABCO}^{+}\right]$cation while only one of them was used in the vibrational analysis of $\left[\mathrm{C}_{8} \mathrm{DABCO}^{+}\right]\left[\mathrm{Br}^{-}\right] \mathrm{IL}$. Reasonable correlations were found between experimental and theoretical vibrational spectra.

\section{Materials and methods}

The reagents used in this study, 1,4-diazabicyclo [2.2.2] octane (>99\%), 1-bromooctane (98\%), ethyl acetate, diethyl ether, were purchased from Fluka and used as received. Deionized $\mathrm{H}_{2} \mathrm{O}$ was obtained with a Millipore ion-exchange resin deionizer.

\subsection{General procedure for the synthesis of DABCO-ILs}

\subsubsection{Synthesis of 1-octyl-1,4-diazabicyclo [2.2.2] octan-1-ium Bromide}

The synthesis procedure was carried out as reported elsewhere [34]. As shown in Scheme 1, 1,4-diazabicyclo [2.2.2] octane (DABCO, $9.95 \mathrm{~g}, 88,7 \mathrm{mmol})$ and 1-bromooctane (18g, 93,2 mmol) were dissolved in AcOEt $(125 \mathrm{ml})$ before being stirred at room temperature $\left(25^{\circ} \mathrm{C}\right)$ for $24 \mathrm{~h}$. The obtained mixture was evaporated under vacuum to remove AcOEt and washed then with diethyl ether $(100 \mathrm{~mL})$ to give the 1-octyl-1,4-diazabicyclo [2.2.2] octan-1-ium Bromide $\left[\mathrm{C}_{8} \mathrm{DABCO}{ }^{+}\right]\left[\mathrm{Br}^{-}\right]$as a yellowish solid $(16,91 \mathrm{~g})$. The yield of this reaction was $57 \%$. Afterwards, the solvent was removed and the $\left[\mathrm{C}_{8} \mathrm{DABCO}^{+}\right]\left[\mathrm{Br}^{-}\right]$was dried under vacuum for $7 \mathrm{~h}$ to obtain a product with high purity. The water content in $\left[\mathrm{C}_{8} \mathrm{DABCO}^{+}\right]\left[\mathrm{Br}^{-}\right]$was $\sim 302$ ppm, this measure was carried out by coulometric Karl Fischer titration, performed by a Metrohm 831. The NMR spectra are presented below.

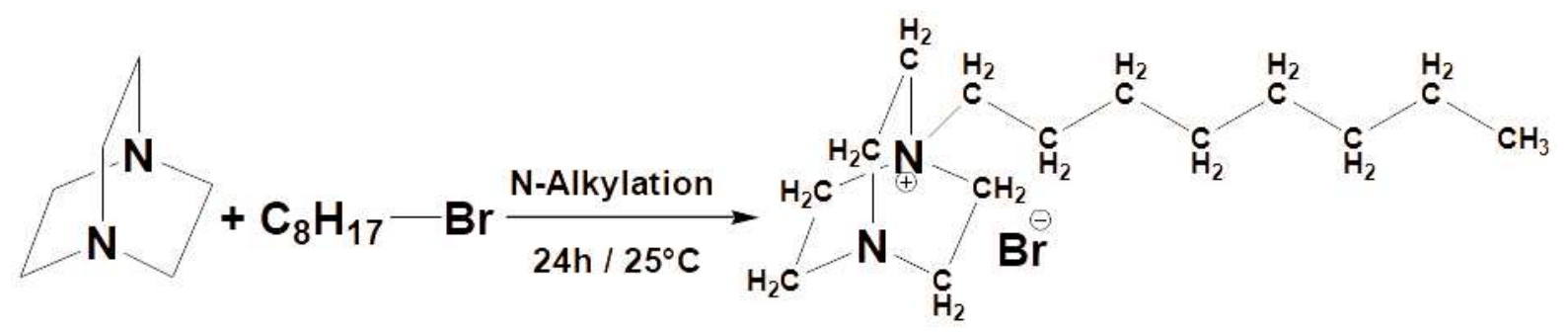

Scheme 1. General synthesis of $\left[\mathrm{C}_{8} \mathrm{DABCO}^{+}\right]\left[\mathrm{Br}^{-}\right]$.

\subsubsection{NMR measurements}


${ }^{1} \mathrm{H}-\mathrm{NMR}(500 \mathrm{MHz})$ and ${ }^{13} \mathrm{C}-\mathrm{NMR}(125.75 \mathrm{MHz})$ characterizations of $\left[\mathrm{C}_{8} \mathrm{DABCO}^{+}\right]\left[\mathrm{Br}^{-}\right]$ were recorded on a Bruker DRX $500 \mathrm{MHz}$ spectrometer. Chemical shifts $(\delta)$ were given in ppm and referenced to the internal signal solvent $\mathrm{CDCl}_{3}$, also, the coupling constants $(\mathrm{J})$ are reported in Hertz $(\mathrm{Hz})$.

\subsubsection{FT-RAMAN measurements}

FT-RAMAN spectra of $\left[\mathrm{C}_{8} \mathrm{DABCO}^{+}\right]\left[\mathrm{Br}^{-}\right]$were acquired on a Vertex 70-RAM II Bruker FTRAMAN spectrometer. This instrument is equipped with a Nd:YAG laser (wavelength 1064 $\mathrm{nm}$, maximum power of $1.5 \mathrm{~W}$ ). The RAM II spectrometer is equipped with a liquid nitrogen cooled Ge detector. FT-RAMAN spectra [45-4000 $\left.\mathrm{cm}^{-1}\right]$ were collected with $1 \mathrm{~cm}^{-1}$ resolution by co-adding 128 scans for spectrum at room temperature.

\subsubsection{Infrared spectroscopy measurements}

The FT-IR spectrum of $\left[\mathrm{C}_{8} \mathrm{DABCO}{ }^{+}\right]\left[\mathrm{Br}^{-}\right]$in the solid phase has been recordedas $\mathrm{KBr}$ pellet in the 4000-600 $\mathrm{cm}^{-1}$ region by Bruker Vertex II-70RAM Spectrometer (Bruker Analytical, Madison, WI) operating with a Golden Gate diamond ATR accessory TM (Specac Ltd, Slough, United Kingdom). The spectral resolution was $1 \mathrm{~cm}^{-1}$ and 64 scans were performed. Both FT-RAMAN and Infrared spectroscopymeasurements were performed in the Walloon Agricultural Research Center (Craw) in Belgium.

\subsection{Computational details}

First, the initial structure of $\left[\mathrm{C}_{8} \mathrm{DABCO}^{+}\right]$cation was modeled with the GaussView program and later, to its structure near to the positively $\mathrm{N}$ charged was added the $\mathrm{Br}$ atom in order to built the $\left[\mathrm{C}_{8} \mathrm{DABCO}{ }^{+}\right]\left[\mathrm{Br}^{-}\right]$IL [35]. After that, both structures were optimized in gas phase with the Revision A.02 of Gaussian 09 program by using the hybrid B3LYP/6-31G* method [36]. Here, it is necessary to clarify that the IL was also optimized with the hybrid B3LYP/6$311++\mathrm{G}^{* *}$ method but the frequencies were not obtained in order to verify the absence of imaginary frequencies. Hence, only the calculations with the B3LYP/6-31G* level of theory were here presented. The structural, electronic and topological properties of both $\left[\mathrm{C}_{8} \mathrm{DABCO}^{+}\right]\left[\mathrm{Br}^{-}\right] \mathrm{IL}$ and its cation were determined with the natural bond orbital (NBO), the Bader's theory of atoms in molecules (AIM) 2000 program [37-39] and atomic charges derived from semiempirical methods [40]. For both species were computed the frontier orbitals and the chemical potential $(\mu)$, electronegativity $(\chi)$, global hardness $(\eta)$, global softness $(S)$, global electrophilicity index $(\omega)$ and global nucleophilicity index $(E)$ descriptors [24-28]. To perform the vibrational assignments of cation were used two harmonic force fields where in one of them, three six members' rings were identified in the cage-like 
structure while in the other one only the deformations of these rings were considered as normal internal coordinates. The definition of rings can be seen in Figure 1 from two different positions of cage-like structure. In the position (a) can be observed the R1 and R2 rings with the identifications of involved atoms in yellow and orange colours, respectively while from the position (b) can be seen the another green ring R3. For a better observation in both cases the side chain was not considered.
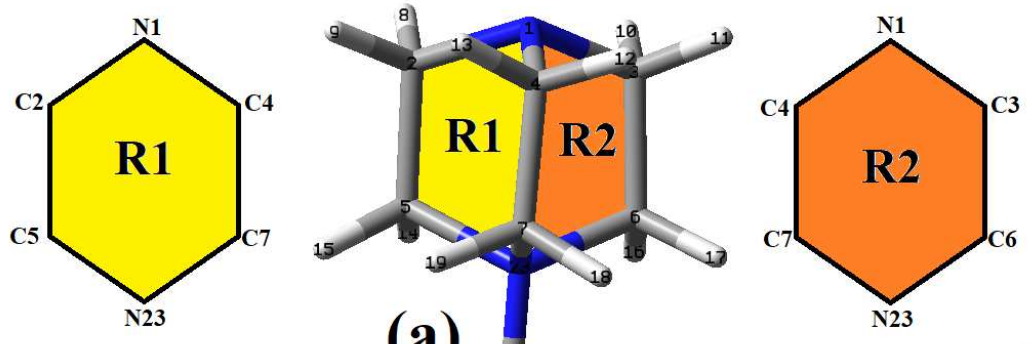

(a)

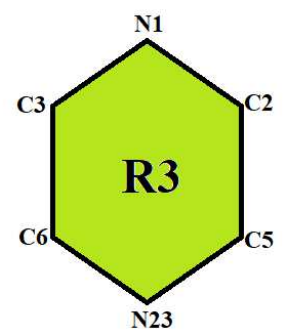

(b)

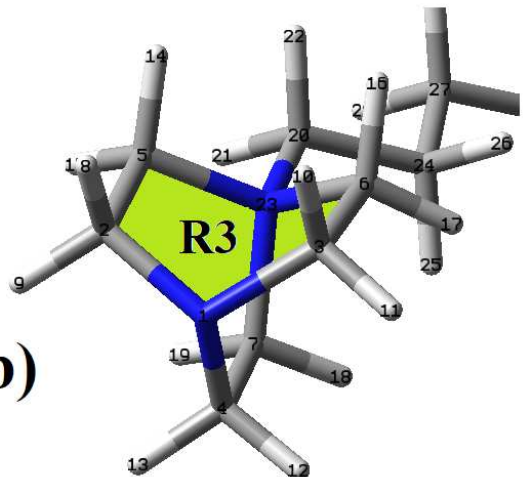

Figure 1. Two different positions of cage corresponding to the molecular structure of $\left[\mathrm{C}_{8} \mathrm{DABCO}{ }^{+}\right]$cation with the identifications of two $\mathrm{R} 1$ and $\mathrm{R} 2$ rings (a) and $\mathrm{R} 3$ ring (b) with the labeling of involved atoms. To a better observation the side chain was not considered.

After that, the normal internal coordinates were defined for the two different harmonic force fields of cation in order to perform the complete vibrational assignments. Then, the vibrational analysis was performed for the $\left[\mathrm{C}_{8} \mathrm{DABCO}+\left[\mathrm{Br}^{-}\right]\right.$IL. For both species transferable scaling factors together with the scaled mechanical force field (SQMFF) and the Molvib program were used [29-31]. For a greater number of vibrational modes, potential energy distribution (PED) contributions $\geq 10 \%$ were used, but in some cases where the modes are strongly coupled, PED values between 8 and $9 \%$ were taken. Recommended equations were used to correct the Raman spectra predicted in activities to intensities $[41,42]$. At last, the ${ }^{1} \mathrm{H}$ and ${ }^{13} \mathrm{C}$ NMR spectra of IL and its cation were predicted by using the gauge independent atomic orbital (GIAO) method at the same level of theory [43]. The Moldraw program was employed to compute the volumes of cation and IL [44]. 


\section{RESULTS AND DISCUSSION}

\subsection{NMR Spectroscopic Characterization}

Both, experimental ${ }^{1} \mathrm{H}$ and ${ }^{13} \mathrm{C}$ NMR are used for confirmation of the structure of synthesized $\left[\mathrm{C}_{8} \mathrm{DABCO}^{+}\right]\left[\mathrm{Br}^{-}\right] \mathrm{IL}$. Hence, Figure $2 \mathbf{a}$ and $\mathbf{2 b}$ show the NMR spectra versus chemical shift dissolved in $\left(\mathrm{CDCl}_{3}\right)$ over the scan range 0 to $4 \delta$ ppm for ${ }^{1} \mathrm{H}$ NMR and from 0 to $70 \delta \mathrm{ppm}$ for ${ }^{13} \mathrm{C} \mathrm{NMR}$. The spectroscopic data are given below.

${ }^{1} \mathbf{H}-\mathbf{N M R}-\left[\mathrm{C}_{8} \mathrm{DABCO}^{+}\right]\left[\mathrm{Br}^{-}\right],\left(\mathrm{CDCl}_{3}\right) \delta_{\mathrm{H}}(\mathrm{ppm})=3.29-3.27(\mathrm{~m}, 6 \mathrm{H}), 3.19-3.18(\mathrm{~m}, 2 \mathrm{H})$, 3.14-3.12 (m, 6H), $1.68(\mathrm{~m}, 2 \mathrm{H}), 1.31-1.25(\mathrm{~m}, 10 \mathrm{H}), 0.87-0.85$ ppm (t, J=5 Hz, 3H). ${ }^{13} \mathbf{C}-$ NMR- $\left[\mathrm{C}_{8} \mathrm{DABCO}^{+}\right]\left[\mathrm{Br}^{-}\right],\left(\mathrm{CDCl}_{3}\right) \delta_{\mathrm{C}}(\mathrm{ppm})=65.05,52.48,45.12,31.50,28.85,26.07,22.37$, $21.73,13.97$.

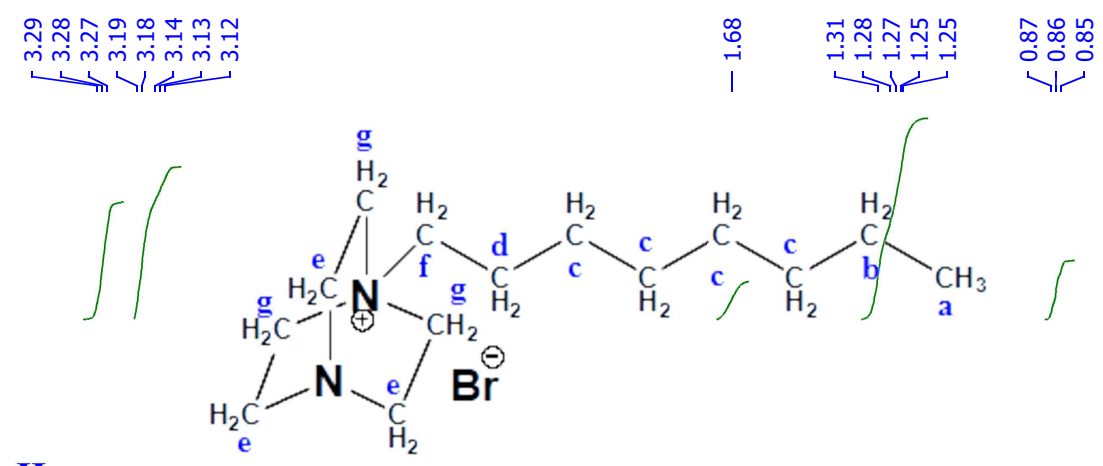

$\mathbf{H}_{\mathrm{g}}$

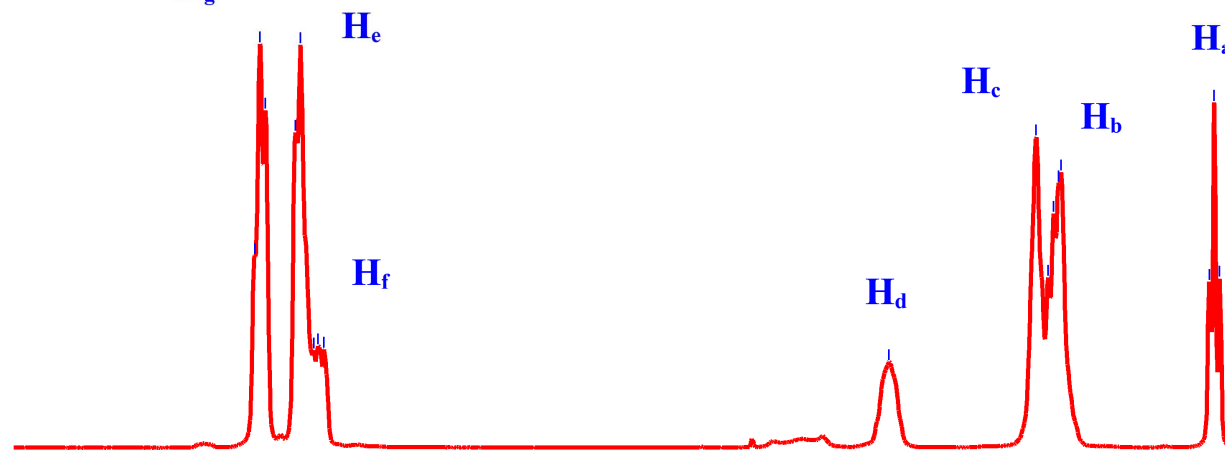

$\mathbf{H}_{\mathbf{a}}$

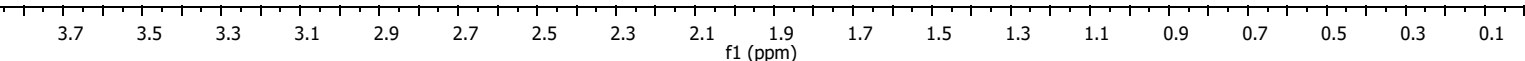




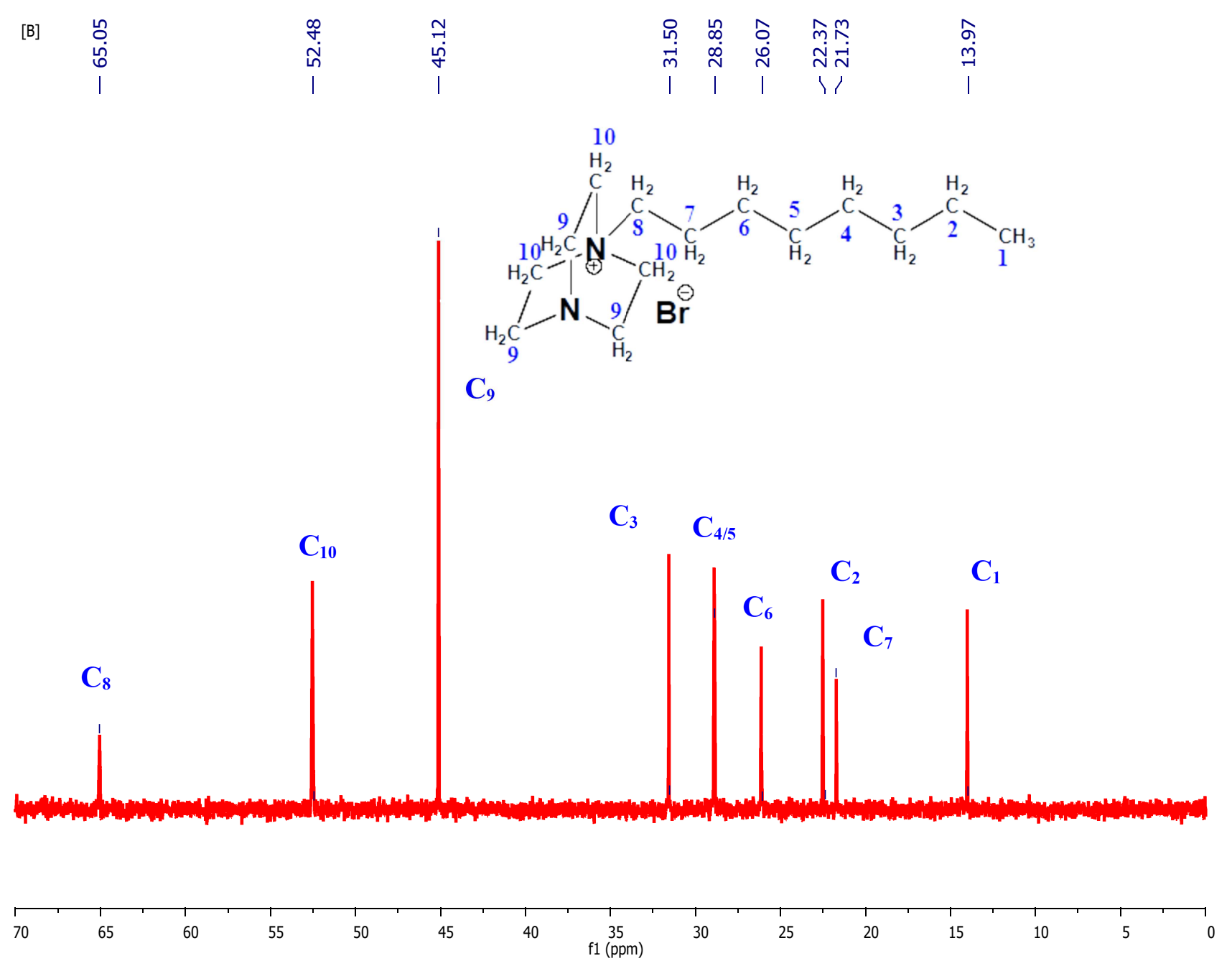

Figure 2. Hydrogen atom labeling and ${ }^{1} \mathrm{H}$ NMR (a), carbon atom labeling and ${ }^{13} \mathrm{C}$ NMR (b) in $\mathrm{CDCl}_{3}$. of $\left[\mathrm{C}_{8} \mathrm{DABCO}^{+}\right]\left[\mathrm{Br}^{-}\right]$.

Based on the corresponding structure of $\left[\mathrm{C}_{8} \mathrm{DABCO}^{+}\right]\left[\mathrm{Br}^{-}\right]$, the ${ }^{1} \mathrm{H}$ NMR spectrum of $\left[\mathrm{C}_{8} \mathrm{DABCO}^{+}\right]\left[\mathrm{Br}^{-}\right]$displayed a triplet peak $\left(\mathrm{H}_{\mathrm{a}}\right)$ between $\delta_{\mathrm{H}}=0.85$ and $0.87 \mathrm{ppm}$ corresponding to terminal methyl group $-\left(\mathrm{CH}_{2}\right)_{\mathrm{n}}-\mathrm{CH}_{3}$, and those $\left(\mathrm{H}_{\mathrm{b}}, \mathrm{H}_{\mathrm{c}}\right)$ between $\delta_{\mathrm{H}}=1.25$ - $1.31 \mathrm{ppm}$ were assigned to $-\left(\mathrm{CH}_{2}\right)_{\mathrm{n}}$ - methylene protons in the Octyl chain [22]. The small NMR spectrum peaks at $\delta_{\mathrm{H}}=1.86 \mathrm{ppm}$ corresponded to $\mathrm{N}-\left(\mathrm{CH}_{2}\right)_{\mathrm{n}}-\left(\mathrm{CH}_{2}\right)-$ methylene protons $\left(\mathrm{H}_{\mathrm{d}}\right)$. The resonances of the methylene rings in DABCO cycle $\left(\mathrm{H}_{\mathrm{e}}\right)$ attached to the tertiary amine are observed around $\delta_{\mathrm{H}}=3.12$ and $13.14 \mathrm{ppm}$, whereas the shift $\left(\mathrm{H}_{\mathrm{f}}\right)$ between $\delta_{\mathrm{H}}=3.18$ and 3.19 ppm was assigned to $\mathrm{N}^{+}-\left(\mathrm{CH}_{2}\right)$. In addition, the deshielded proton $\left(\mathrm{H}_{\mathrm{g}}\right)$ attached to the quaternary $\mathrm{N}^{+}$atom were displayed at $\delta_{\mathrm{H}}=3.27$ and $3.29 \mathrm{ppm}$ [23]. On the other hand, the ${ }^{13} \mathrm{C}-\mathrm{NMR}$ spectrum of $\left[\mathrm{C}_{8} \mathrm{DABCO}^{+}\right]\left[\mathrm{Br}^{-}\right]$shows very clearly nine signals between $\delta_{\mathrm{C}}=65.05$ and $13.97 \mathrm{ppm}$ confirm the N-alkylation of DABCO system by Octyl 
chain and corresponding to the appropriate structure of $\left[\mathrm{C}_{8} \mathrm{DABCO}{ }^{+}\right]\left[\mathrm{Br}^{-}\right]$. Therefore, both spectra clearly confirms that $\left[\mathrm{C}_{8} \mathrm{DABCO}^{+}\right]\left[\mathrm{Br}^{-}\right]$has been synthesized successfully. The optimized structures of $\left[\mathrm{C}_{8} \mathrm{DABCO}^{+}\right]\left[\mathrm{Br}^{-}\right] \mathrm{IL}$ and its cation are presented in Figure 3 together with the atoms labelling. Comparisons of experimental chemical shifts of protons and $\mathrm{C}$ atoms with the corresponding predicted by using Gauge-Independent Atomic Orbital (GIAO) method [43] with the hybrid B3LYP/6-31G* method are shown in Tables 1 and 2.

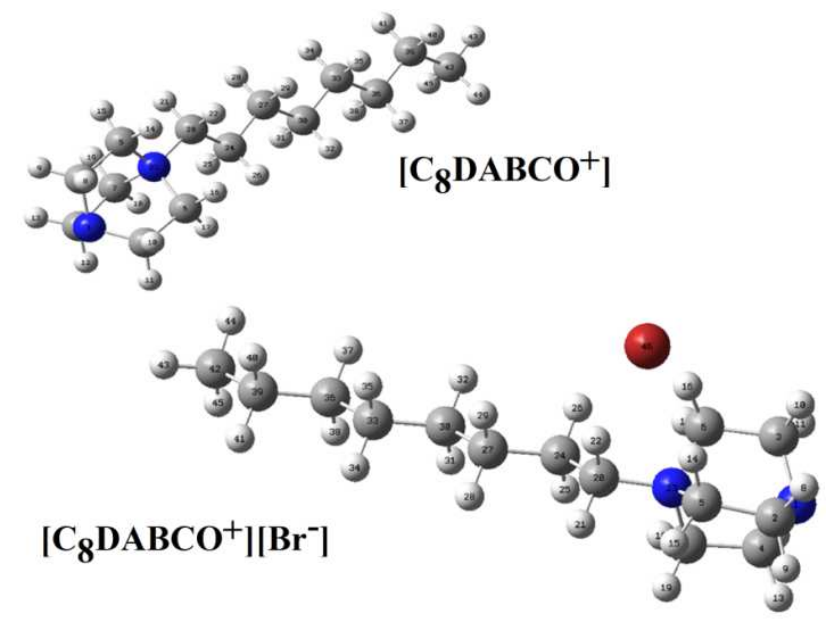

Figure 3. Optimized theoretical structures of $\left[\mathrm{C}_{8} \mathrm{DABCO}^{+}\right]\left[\mathrm{Br}^{-}\right]$IL and its cation by using the hybrid B3LYP/6-31G* method together with atoms labeling.

Table 1. Observed and calculated ${ }^{1} \mathrm{H}$ chemical shifts $\left(\delta\right.$ in ppm) of $\left[\mathrm{C}_{8} \mathrm{DABCO}^{+}\right]\left[\mathrm{Br}^{-}\right]$IL and its cation in gas phase by using the hybrid B3LYP/6-31G* method.

\begin{tabular}{cccc}
\hline Atoms & {$\left[\mathrm{C}_{8} \mathrm{DABCO}{ }^{+}\right]$} & {$\left[\mathrm{C}_{8} \mathrm{DABCO}^{+}\right]$} & Exp. $^{{ }^{\mathrm{a}}}$ \\
\hline $8-\mathrm{H}$ & 2.98 & 2.83 & 3.18 \\
$9-\mathrm{H}$ & 2.91 & 2.30 & 3.18 \\
$10-\mathrm{H}$ & 2.89 & 2.85 & 3.19 \\
$11-\mathrm{H}$ & 2.95 & 2.34 & 3.19 \\
$12-\mathrm{H}$ & 2.85 & 2.49 & 3.14 \\
$13-\mathrm{H}$ & 2.97 & 2.59 & 3.14 \\
$14-\mathrm{H}$ & 2.43 & 6.74 & 3.27 \\
$15-\mathrm{H}$ & 2.43 & 1.52 & 3.27 \\
$16-\mathrm{H}$ & 2.25 & 7.01 & 3.29 \\
$17-\mathrm{H}$ & 2.70 & 1.75 & 3.29 \\
$18-\mathrm{H}$ & 2.81 & 2.49 & 3.28 \\
$19-\mathrm{H}$ & 2.18 & 1.74 & 3.28 \\
$21-\mathrm{H}$ & 2.51 & 1.42 & 3.13 \\
$22-\mathrm{H}$ & 2.55 & 6.68 & 3.12 \\
$25-\mathrm{H}$ & 1.31 & 0.87 & 1.68 \\
$26-\mathrm{H}$ & 1.33 & 1.48 & 1.68 \\
$28-\mathrm{H}$ & 1.07 & 0.72 & 1.31 \\
$29-\mathrm{H}$ & 1.08 & 1.50 & 1.31
\end{tabular}




\begin{tabular}{cccc}
$31-\mathrm{H}$ & 1.26 & 1.03 & 1.27 \\
$32-\mathrm{H}$ & 1.26 & 1.25 & 1.27 \\
$34-\mathrm{H}$ & 1.20 & 1.06 & 1.28 \\
$35-\mathrm{H}$ & 1.20 & 1.27 & 1.28 \\
$37-\mathrm{H}$ & 1.18 & 1.16 & 1.25 \\
$38-\mathrm{H}$ & 1.18 & 1.06 & 1.25 \\
$40-\mathrm{H}$ & 1.21 & 1.20 & 1.25 \\
$41-\mathrm{H}$ & 1.21 & 1.13 & 1.25 \\
$43-\mathrm{H}$ & 0.99 & 0.83 & 0.87 \\
$44-\mathrm{H}$ & 0.71 & 0.65 & 0.86 \\
$45-\mathrm{H}$ & 0.71 & 0.61 & 0.85 \\
\hline RMSD & $\mathbf{0 . 4 5}$ & $\mathbf{1 . 3 6}$ \\
\hline \multicolumn{3}{c}{ aThis work }
\end{tabular}

Table 2. Observed and calculated ${ }^{13} \mathrm{C}$ chemical shifts ( $\delta$ in ppm) of $\left[\mathrm{C}_{8} \mathrm{DABCO}^{+}\right]\left[\mathrm{Br}^{-}\right] \mathrm{IL}$ and its cation in gas phase by using the hybrid B3LYP/6-31G* method.

\begin{tabular}{c|c|c|c}
\hline Atoms & cation & IL & Experimental \\
\hline 2-C & 38.29 & 38.85 & 45.12 \\
3-C & 38.16 & 38.40 & 45.12 \\
4-C & 38.16 & 39.08 & 45.12 \\
5-C & 50.32 & 45.78 & 52.48 \\
6-C & 44.85 & 40.20 & 52.48 \\
7-C & 44.69 & 44.51 & 52.48 \\
20-C & 60.65 & 53.74 & 65.05 \\
24-C & 17.16 & 17.05 & 21.73 \\
27-C & 22.23 & 21.66 & 26.07 \\
30-C & 25.50 & 25.92 & 28.85 \\
33-C & 25.58 & 25.73 & 28.85 \\
36-C & 26.87 & 27.31 & 31.50 \\
39-C & 18.72 & 18.91 & 22.37 \\
42-C & 8.46 & 9.03 & 13.97 \\
\hline RMSD & $\mathbf{5 . 4 1}$ & $\mathbf{6 . 6 6}$ & \\
\hline \multicolumn{3}{|c}{ 'This work }
\end{tabular}

These chemical shifts are relatively well reproduced for both nuclei with deviations between 0.45 and $1.36 \mathrm{ppm}$ for $\mathrm{H}$ atoms and between 5.41 and $6.66 \mathrm{ppm}$ for $\mathrm{C}$ atoms. The differences observed can be attributed to the calculations and the method used because the NMR calculations were performed in gas phase and with the B3LYP/6-31G*. Note that the cation is better reproduced than the IL probably due to the cation-anion interactions observed in the IL.

\subsection{Geometries}

In Figure 3 have been shown the optimized structures of $\left[\mathrm{C}_{8} \mathrm{DABCO}+\left[\mathrm{Br}^{-}\right]\right.$IL and its cation in gas phase by using the hybrid B3LYP/6-31G* method together with the atoms labelling. Both structures present $C_{l}$ symmetries. Total energies uncorrected and corrected by zero 
point vibrational energy (ZPVE), dipole moments and volumes of those two species in gas phase by using the B3LYP/6-31G* method are summarized in Table 3. Note that the incorporation of $\mathrm{Br}$ in the cation produces few increases in the dipole moment value from 9.90 D in the cation to $11.61 \mathrm{D}$ in $\mathrm{IL}$, however, due to great size of this atom and to its electronegativity value a larger volume expansion is observed in the $\left[\mathrm{C}_{8} \mathrm{DABCO}{ }^{+}\right]\left[\mathrm{Br}^{-}\right] \mathrm{IL}$ $\left(26.3 \AA^{3}\right)$.

Table 3. Calculated total energies $(E)$, dipole moments $(\mu)$ and volumes $(V)$ of $\left[\mathrm{C}_{8} \mathrm{DABCO}{ }^{+}\right]$ $\left[\mathrm{Br}^{-}\right]$ionic liquid and its cation in gas phase by using the B3LYP/6-31G* method.

\begin{tabular}{cccccc}
\hline \multicolumn{7}{c}{ B3LYP/6-31G* Method } \\
\hline Species & E (Hartrees) & ZPVE (Hartrees) & $\mu(\mathrm{D})$ & $\mathrm{V}\left(\AA^{3}\right)$ & $\Delta \mathrm{V}\left(\AA^{3}\right)$ \\
\hline$\left[\mathrm{C}_{8} \mathrm{DABCO}{ }^{+}\right]\left[\mathrm{Br}^{-}\right]$ & -3232.1483 & -3231.7201 & 11.61 & 325.6 & 26.3 \\
{$\left[\mathrm{C}_{8} \mathrm{DABCO}^{+}\right]$} & -660.2297 & -659.8018 & 9.90 & 299.3 & \\
\hline
\end{tabular}

When the orientations and directions of dipole moment vectors of both species are graphed in Figure S1 it is observed important changes in the direction, magnitude and orientation of vector corresponding to IL. In the cation, the orientation of vector is axial and is directed toward the cage while in the IL the orientation is equatorial and directed in the sense contrary to $\mathrm{Br}$ atom. Hence, due to size and to the electronegativity of $\mathrm{Br}$ its effect in the IL is that generates changes in the orientation, direction and magnitude of dipole moment vector. Probably, the interactions of cation with the $\mathrm{Br}$ anion play a important role in the properties of $\left[\mathrm{C}_{8} \mathrm{DABCO}^{+}\right]\left[\mathrm{Br}^{-}\right] \mathrm{IL}$, as evidenced in the three $\mathrm{C}-\mathrm{H} \cdots \mathrm{Br}$ interactions predicted in the optimized structure (Figure S2) by using the Moldraw program [44]. Changes in the geometrical parameters of groups closer to $\mathrm{Br}$ atom are expected and, for these reasons, calculated geometrical parameters of $\left[\mathrm{C}_{8} \mathrm{DABCO}^{+}\right]\left[\mathrm{Br}^{-}\right] \mathrm{IL}$ and its cation in gas phase by using the B3LYP/6-31G* method are compared in Table 4.

Table 4. Calculated geometrical parameters of $\left[\mathrm{C}_{8} \mathrm{DABCO}{ }^{+}\right]\left[\mathrm{Br}^{-}\right]$ionic liquid and its cation in gas phase by using the B3LYP/6-31G* Method.

\begin{tabular}{ccccc}
\hline \multicolumn{5}{c}{ B3LYP/6-31G* Method $^{\mathrm{a}}$} \\
\hline Parameters & {$\left[\mathrm{C}_{8} \mathrm{DABCO}{ }^{+}\right]$} & \multicolumn{4}{c}{$\left[\mathrm{C}_{8} \mathrm{DABCO}{ }^{+}\right]\left[\mathrm{Br}^{-}\right]$} \\
\hline N1-C2 & 1.463 & 1.469 & $\mathrm{H} 14-\mathrm{Br} 46$ & 2.501 \\
N1-C3 & 1.463 & 1.471 & $\mathrm{H} 16-\mathrm{Br} 46$ & 2.459 \\
N1-C4 & 1.463 & 1.463 & $\mathrm{H} 22-\mathrm{Br} 46$ & 2.530 \\
N23-C5 & 1.524 & 1.528 & & \\
N23-C6 & 1.521 & 1.526 & & \\
N23-C7 & 1.521 & 1.507 & & \\
C5-H14 & 1.092 & 1.100 &
\end{tabular}




\begin{tabular}{|c|c|c|c|c|}
\hline C6-H16 & 1.092 & \multicolumn{3}{|l|}{1.100} \\
\hline $\mathrm{C} 20-\mathrm{H} 22$ & 1.094 & \multicolumn{3}{|l|}{1.100} \\
\hline \multicolumn{5}{|c|}{ Bond angles $\left({ }^{\circ}\right)$} \\
\hline Parameters & {$\left[\mathrm{C}_{8} \mathrm{DABCO}^{+}\right]$} & & {$\left[\mathrm{C}_{8} \mathrm{DABCO}^{+}\right]\left[\mathrm{Br}^{-}\right.$} & \\
\hline C2-N1-C3 & 109.5 & 108.4 & C5-H14-Br46 & 151.2 \\
\hline C2-N1-C4 & 109.5 & 109.0 & C6-H16-Br46 & 149.8 \\
\hline C3-N1-C4 & 109.6 & 109.2 & C20-H22-Br46 & 149.2 \\
\hline C5-N23-C6 & 108.2 & 108.4 & & \\
\hline C5-N23-C7 & 108.1 & 108.3 & & \\
\hline C6-N23-C7 & 108.6 & 108.4 & & \\
\hline
\end{tabular}

The exhaustive inspection of Table 4 shows that the distances related to N1-C2, N1-C3 and N1-C4 bonds undergoes few changes in the IL (0.008-0.006 $\AA$ ) while the longer differences are observed in the N23-C7 bond that decreases in the IL in $0.014 \AA$, as compared with the observed value in the cation. Also, the C-H distances increase from 1.092/1.094 $\AA$ in the cation to $1.100 \AA$ in the IL. Note that the distances of three $\mathrm{C}-\mathrm{H} \cdots \mathrm{Br}$ interactions have different values, having the $\mathrm{H} 16-\mathrm{Br} 46$ bond the lowest value. Few changes are observed in the bond angles, presenting the C2-N1-C3 angle a shortening of $1^{\circ}$ in the IL. Then, observing those three $\mathrm{C}-\mathrm{H} \cdots \mathrm{Br}$ interactions only one of them $(\mathrm{C} 5-\mathrm{H} 14-\mathrm{Br} 46)$ presents a higher angle $\left(151.2^{\circ}\right)$, as compared with the other two. These studies show that the three interactions present different characteristics, for which only one of them will present strong coordination between cation-anion $(\mathrm{C} 6-\mathrm{H} 16 \cdots \mathrm{Br} 46)$ and, hence, a monodentate coordination between these two species could be proposed for this $\left[\mathrm{C}_{8} \mathrm{DABCO}^{+}\right]\left[\mathrm{Br}^{-}\right]$IL. The only cation-anion C6$\mathrm{H} 16 \cdots \mathrm{Br} 46$ interaction can be seen in Figure 4.

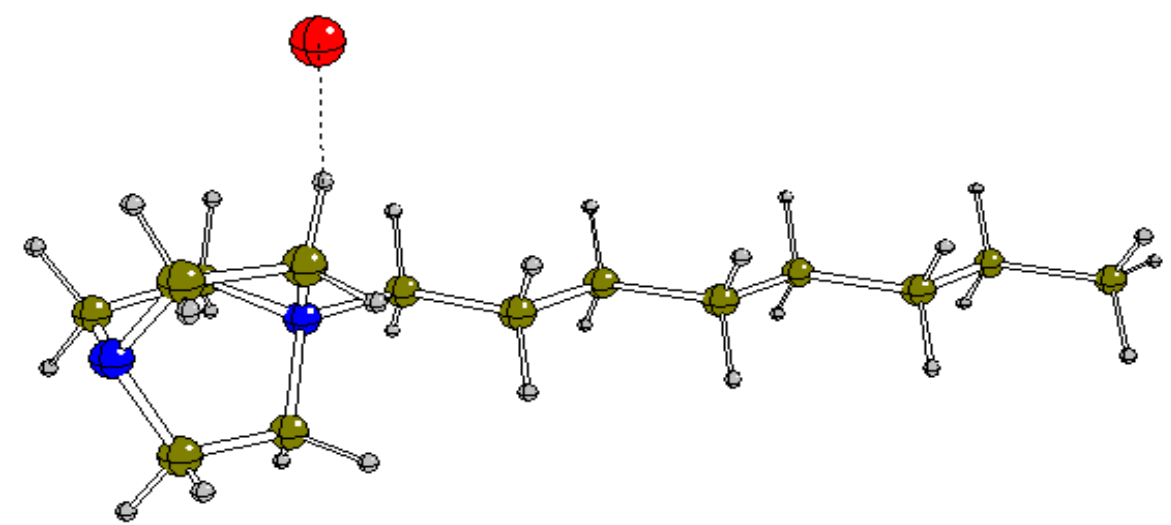

Figure 4. Monodentate coordination proposed between cation and anion of $\left[\mathrm{C}_{8} \mathrm{DABCO}{ }^{+}\right]$ $\left[\mathrm{Br}^{-}\right]$ionic liquid in gas phase by using the B3LYP/6-31G* method showing the formation of strongest $\mathrm{C} 6-\mathrm{H} 6 \cdots \mathrm{Br} 46$ interaction.

\subsection{Atomic charges, molecular electrostatic potentials and bond orders}


The studies of atomic charges are of great interest in the $\left[\mathrm{C}_{8} \mathrm{DABCO}{ }^{+}\right]\left[\mathrm{Br}^{-}\right] \mathrm{IL}$ and its cation due to the two tertiary and quaternary $\mathrm{N}$ atoms present in the diazabicyclic as a cage-like structure and to the presence of $\mathrm{Br}$ in the IL that due to its size and electronegativity generate strong cation-anion interactions. For these reasons, atomics Merz-Kollman (MK), Mulliken and natural population analysis (NPA) charges were computed only on those atoms involved in the cage and in the $\mathrm{C}-\mathrm{H} \cdots \mathrm{Br}$ interactions. Hence, in Table $\mathrm{S} 1$ can be seen the three types of atomic charges for both species in gas phase by using the B3LYP/6-31G* method and, also, the molecular electrostatic potentials (MEP) and bond orders (BO), expressed as Wiberg indexes. The behaviours of those three atomic charges for the two species are shown in Figure S3. Quick evaluations of three charges from Figure S3 show that the Mulliken and NPA charges present practically the same behaviours on all atoms, having the most positive values on the $\mathrm{H} 14$ and $\mathrm{H} 22$ atoms while on N1 and N23 the most negative values. Besides, both charges on the six $\mathrm{C}$ atoms have approximately the same values and, only differences in the values on N1 and N23 are observed. Thus, the Mulliken charge on N23 has the most negative value than N1 while the NPA charges predict a contrary resulted. On the contrary, the MK charges in both species show important differences on all atoms. Thus, on C5, C6, $\mathrm{H} 22$ and N23 of IL are observed positive values while on the other ones negative values but, in the cation only are observed positive values on the H14, H22 and N23 atoms. These studies reveal that only the MK charges values on the atoms corresponding to the cage structure and to the $\mathrm{H}$ atoms support the $\mathrm{C} 5-\mathrm{H} 14 \cdots \mathrm{Br} 46, \mathrm{C} 6-\mathrm{H} 16 \cdots \mathrm{Br} 46$ and $\mathrm{C} 20-$ $\mathrm{H} 22 \cdots \mathrm{Br} 46$ interactions predicted in the IL.

When the molecular electrostatic potentials (MEP) are evaluated from Table S1 only are observed the expected tendency, $\mathrm{N}>\mathrm{C}>\mathrm{H}$ where both $\mathrm{N}$ atoms present the most negative values while the three $\mathrm{H}$ atoms the less negative values. Here, the lower MEPs values observed on the H14 and H16 atoms, as compared with H22, reveal that these two atoms are most labile than the other one. Besides, in the two species the MEPs on N1 show higher values than N23 but, the most important result is that the MEPs values on all atoms of cation increase in the IL due to effect of Br. If now the mapped MEPs surfaces for $\left[\mathrm{C}_{8} \mathrm{DABCO}{ }^{+}\right]$ [Br-] IL and its cation are graphed with the GaussView program in Figure S4 [35] we observed clearly the effect of $\mathrm{Br}$ on the MEPs values. Therefore, strong blue colours are observed on the cage structure of cation which are typical of electrophilic sites while on the side chain ligth blue colours it is observed indicating a less electrophilic region. In the $\left[\mathrm{C}_{8} \mathrm{DABCO}{ }^{+}\right]\left[\mathrm{Br}^{-}\right] \mathrm{IL}$ around of $\mathrm{Br}$ anion, there is a high electron density accumulate with 
strong red colour characteristic of nucleophilic sites on the entire region while on the cage can be observed light blue colours indicating weak electrophilic regions. The green colours in side chain of IL indicate inert regions.

The characteristics of three different $\mathrm{C}-\mathrm{H} \cdots \mathrm{Br}$ interactions can be studied by means of the bond orders (BO), expressed as Wiberg indexes because these parameters show the nature or type of bonds. Hence, for the $\left[\mathrm{C}_{8} \mathrm{DABCO}^{+}\right]\left[\mathrm{Br}^{-}\right] \mathrm{IL}$ and its cation the $\mathrm{BOs}$ can be seen in Table S1. The BO values in the IL decrease with respect to cation and only a slight increase is observed in the N23 atom. Higher values are observed in the N23 of both species, as compared with the corresponding to N1. This result is the expected because the N23 atom is positively charged. Thus, when the Wiberg bond index matrix in the NAO basis for the Br46 atom is analyzed the higher BOs values are observed for the H14, H16 and H22 atoms with values respectively of $0.0669,0.0718$ and 0.0606 . Note that for the H16 the value is greater than the other ones, for which, the $\mathrm{C} 6-\mathrm{H} 16^{\cdots} \mathrm{Br} 46$ interaction is stronger than the other ones and, hence, these analyses also support the monodentate coordination between the cation and Br anion.

\subsection{NBO and AIM studies}

Two types de calculations were performed for the $\left[\mathrm{C}_{8} \mathrm{DABCO}{ }^{+}\right]\left[\mathrm{Br}^{-}\right]$IL and its cation in order to evaluate the interactions predicted for the IL when the $\mathrm{Br}$ anion is incorporated to cation. In the first study, energies of possible interactions between 'filled' (donor) Lewis-type NBOs and 'empty' (acceptor) non-Lewis NBOs were estimated by using 2nd-order perturbation theory Analysis of Fock Matrix in NBO Basis with the NBO program [37]. In the other study, the topological properties were also employed to investigate different interactions according to the Bader's theory in addition to those $\mathrm{C}-\mathrm{H} \cdots \mathrm{Br}$ previously predicted in the IL $[38,39]$. Thus, main delocalization energies of $\left[\mathrm{C}_{8} \mathrm{DABCO}^{+}\right]\left[\mathrm{Br}^{-}\right]$ionic liquid and its cation calculated with the NBO program in gas phase by using the B3LYP/631G* method are presented in Table S2. The results shown in the table have evidenced the presence of three new $n \rightarrow \sigma^{*}$ interactions $\left(L P(1) N 1 \rightarrow \sigma^{*} C-C\right)$ in the IL which are carried out from lone pairs of $\mathrm{N} 1$ atoms to anti-bonding $\mathrm{C}-\mathrm{C}$ orbitals but, in addition, in the IL are also observed the three $\mathrm{C} 5-\mathrm{H} 14 \cdots \mathrm{Br} 46, \mathrm{C} 6-\mathrm{H} 16 \cdots \mathrm{Br} 46$ and $\mathrm{C} 20-\mathrm{H} 22 \cdots \mathrm{Br} 46$ interactions $\left(L P(4) B r 46 \rightarrow \sigma^{*} C-H\right)$ predicted in the above studies. Here, the $L P(4) B r 46 \rightarrow \sigma^{*} C 6-H 16$ interaction presents the higher energy value $(32.35 \mathrm{~kJ} / \mathrm{mol})$ in agreement with the higher properties observed for this interaction by MK charges, MEPs and BOs studies. The total 
energy favours to IL with a value of $185.80 \mathrm{~kJ} / \mathrm{mol}$ while for the cation the value is 54.21 $\mathrm{kJ} / \mathrm{mol}$. Clearly, the $\mathrm{Br}$ anion stabilizes strongly to cation to form the IL.

Other form to evaluate different types of interactions is by means of the topological properties through the determinations of electron density, $\rho(r)$, the Laplacian values, $\nabla^{2} \rho(r)$, the eigenvalues $(\lambda 1, \lambda 2, \lambda 3)$ of the Hessian matrix and, the $|\lambda 1| / \lambda 3$ ratio calculated with the AIM 2000 program in the bond critical points (BCPs) and ring critical points (RCPs) [38,39]. If the $\lambda 1 / \lambda 3<1$ and $\nabla^{2} \rho(r)>0$ the interaction is ionic, highly polar covalent or hydrogen bonds (closed-shell interaction). These topological properties predicted for IL and its cation in gas phase by using the B3LYP/6-31G*an be observed in Table S3. In Figure S5 is shown the molecular graphic of $\left[\mathrm{C}_{8} \mathrm{DABCO}^{+}\right]$cation in gas phase by using the $\mathrm{B} 3 \mathrm{LYP} / 6$ -

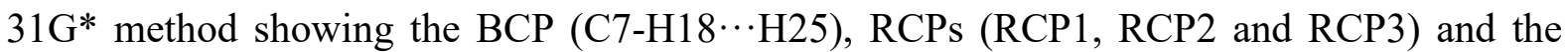
cage critical point (CCP). The three RCP1, RCP2 and RCP3 rings form the cage CCP whose eigenvalues of the Hessian matrix present all positive signs, as can be seen in Table S3. The BCPs are identified in red colours, the RCPs in yellow while the CCP with green colour. In Figure 5 is presented the molecular graphic of $\left[\mathrm{C}_{8} \mathrm{DABCO}^{+}\right]\left[\mathrm{Br}^{-}\right]$ionic liquid in gas phase by using the same level of theory showing four BCPs (C5-H14 $\cdots \mathrm{Br} 46, \mathrm{C} 6-\mathrm{H} 16 \cdots \mathrm{Br} 46$ and $\mathrm{C} 20$ $\mathrm{H} 22 \cdots \mathrm{Br} 46$ and $\mathrm{C} 7-\mathrm{H} 18 \cdots \mathrm{H} 25)$, three RCPs (RCP1, RCP2 and RCP3) and the new RCPN1, RCPN2, RCPN3 and RCPN4. Note that the three RCPs origin the CCP1 while the other new three RCPN2, RCPN3 and RCPN4 origin the CCP2. To the identification, around these new RCPNs can be seen squares in yellow colours. Clearly, the IL is most stable than the cation due to $\mathrm{Br}$ anion.

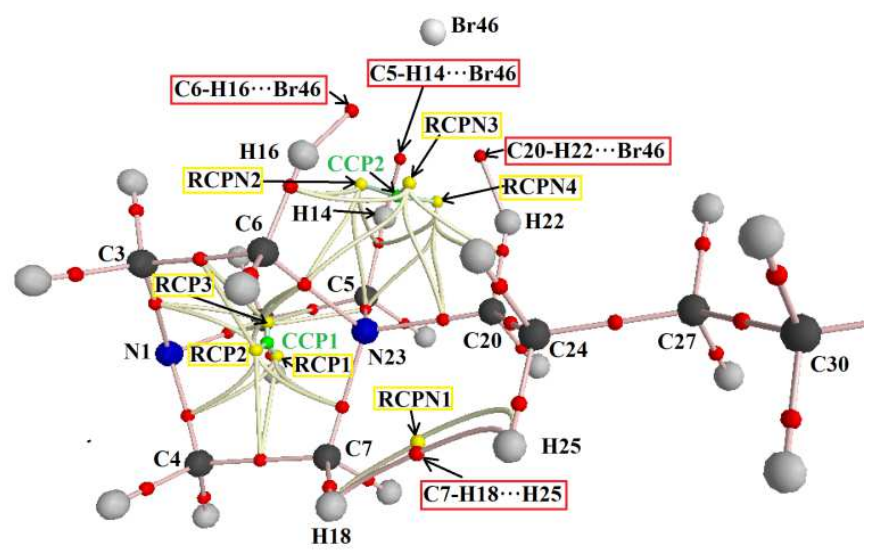

Figure 5. Molecular graphic of $\left[\mathrm{C}_{8} \mathrm{DABCO}^{+}\right]\left[\mathrm{Br}^{-}\right]$ionic liquid in gas phase by using the B3LYP/6-31G* method showing the BCP and the RCPs and the CCPs.

The distances between the involved atoms in the $\mathrm{C}-\mathrm{H} \cdots \mathrm{Br}$ interactions are between 2.459 and $2.530 \AA$ revealing the higher value the $\mathrm{C} 6-\mathrm{H} 16 \cdots \mathrm{Br} 46$ interaction and, hence, this interaction 
supports the monodentate coordination between cation and anion, as have suggested the previous sections.

\subsection{Frontier orbitals and quantum chemical descriptors}

Frontier orbitals, gap values and chemical potential $(\mu)$, electronegativity $(\chi)$, global hardness $(\eta)$, global softness $(S)$, global electrophilicity index $(\omega)$ and global nucleophilicity index $(E)$ descriptors were calculated for the $\left[\mathrm{C}_{8} \mathrm{DABCO}^{+}\right]\left[\mathrm{Br}^{-}\right]$ionic liquid and its cation in order to predict the reactivities and behaviours taking into account that both species have cage structures with two $\mathrm{N}$ atoms (one with three organic substituents and the other one with four organic substituents and positively charged) [24-28]. These parameters calculated in gas phase by using the B3LYP/6-31G* method are compared in Table S4 with reported for [Aliquat $\left.{ }^{+}\right]\left[\mathrm{Cl}^{-}\right]$[27], [Aliquat $\left.{ }^{+}\right]\left[\mathrm{NTf}_{2}^{-}\right]$[28], [EMIM $\left.{ }^{+}\right]\left[\mathrm{PF}_{6}^{-}\right]$26], [BMIM][OTF] [25] and $[\mathrm{BMIM}]\left[\mathrm{NO}_{3}\right][24]$ ionic liquids with the same level of theory and with the B3LYP/6-311+ $+\mathrm{G}^{* *}$ method. Analyzing first the gap values for $\left[\mathrm{C}_{8} \mathrm{DABCO}^{+}\right]\left[\mathrm{Br}^{-}\right]$ionic liquid and its cation we observed that the $\mathrm{Br}$ anion reduces the gap value of cation from $7.1512 \mathrm{eV}$ to $5.0558 \mathrm{eV}$ in the IL and, for this reason, the $\mathrm{Br}$ confers a higher reactivity to $\left[\mathrm{C}_{8} \mathrm{DABCO}{ }^{+}\right]\left[\mathrm{Br}^{-}\right]$. If now, that IL is compared with the other ones, the 1-buthyl-3-methyl imidazolium nitrate IL $\left([\mathrm{BMIM}]\left[\mathrm{NO}_{3}\right]\right)$ is the most reactive with the lowest gap value $(4.2180 \mathrm{eV})$. However, the cage structure of $\left[\mathrm{C}_{8} \mathrm{DABCO}{ }^{+}\right]\left[\mathrm{Br}^{-}\right]$ionic liquid increase the reactivity against to [Aliquat $\left.{ }^{+}\right]$ $\left[\mathrm{Cl}^{-}\right][27]$ and [Aliquat $\left.{ }^{+}\right]\left[\mathrm{NTf}_{2}{ }^{-}\right]$[28]. Also, the [Aliquat $\left.{ }^{+}\right]\left[\mathrm{Cl}^{-}\right] \mathrm{IL}$ [27] is most reactive than 1Ethyl-3-methylimidazolium hexafluorophosphate ([EMIM $\left.\left.\left.{ }^{+}\right]\left[\mathrm{PF}_{6}^{-}\right] 26\right]\right)$. Thus, the $\mathrm{Cl}$ anion reduces the gap value of $\left[\right.$ Aliquat $\left.{ }^{+}\right]$cation, as compared with $\left[\mathrm{NTf}_{2}{ }^{-}\right]$. When the descriptors are evaluated, it is observed that the most reactive species have higher global electrophilicity indexes $(\omega)$ ([BMIM][OTF] [25] and [BMIM] $\left[\mathrm{NO}_{3}\right]$ [24]) while the global nucleophilicity indexes $(E)$ show values between -9.032 and $-7.3035 \mathrm{eV}$. Probably, the higher reactivity observed for $[\mathrm{BMIM}]\left[\mathrm{NO}_{3}\right]$ could be justified by the higher global electrophilicity index $(\omega)$ and the lowest chemical potential $(\mu)$ than the other ones.

\subsection{Vibrational study}

The experimental FT-IR and FT-Raman of $\left[\mathrm{C}_{8} \mathrm{DABCO}^{+}\right]\left[\mathrm{Br}^{-}\right]$ionic liquid in the solid state are presented in Figures 6 and 7, respectively compared with the corresponding predicted in the gas phase for IL and its cation by using the B3LYP/6-31G* method. Both predicted spectra show very good correlations with the corresponding experimental ones and, especially when the theoretical Raman spectra are corrected from activities to intensities 
$[41,42]$. Due to the presence of 45 and 46 atoms in the cation and $\left[\mathrm{C}_{8} \mathrm{DABCO}^{+}\right]\left[\mathrm{Br}^{-}\right]$ionic liquid 129 and 132 vibration modes are expected respectively in these species. The two structures were optimized in gas phase with $C_{1}$ symmetries by using B3LYP/6-31G* calculations and, hence, all vibration modes show activity in the infrared and Raman spectra.

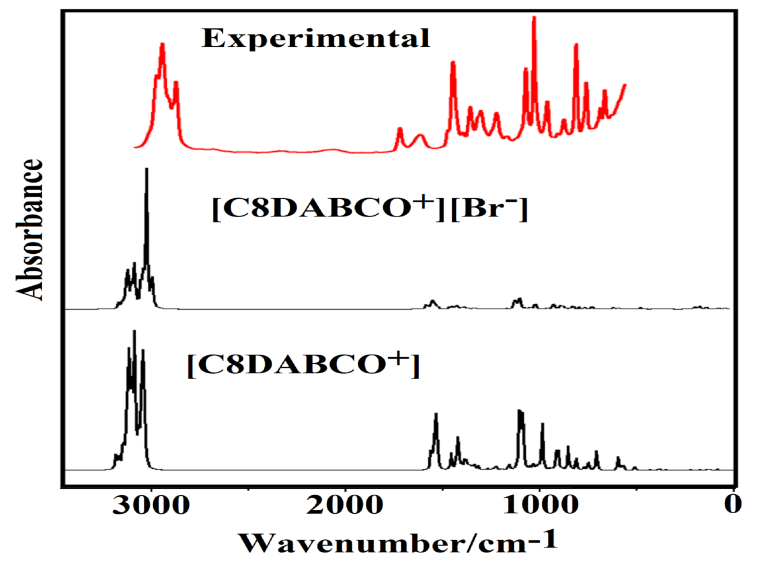

Figure 6. Experimental FT-IR of $\left[\mathrm{C}_{8} \mathrm{DABCO}^{+}\right]\left[\mathrm{Br}^{-}\right]$ ionic liquid in the solid phase compared with the corresponding predicted for IL and cation in gas phase by using the hybrid B3LYP/6-31G* method.

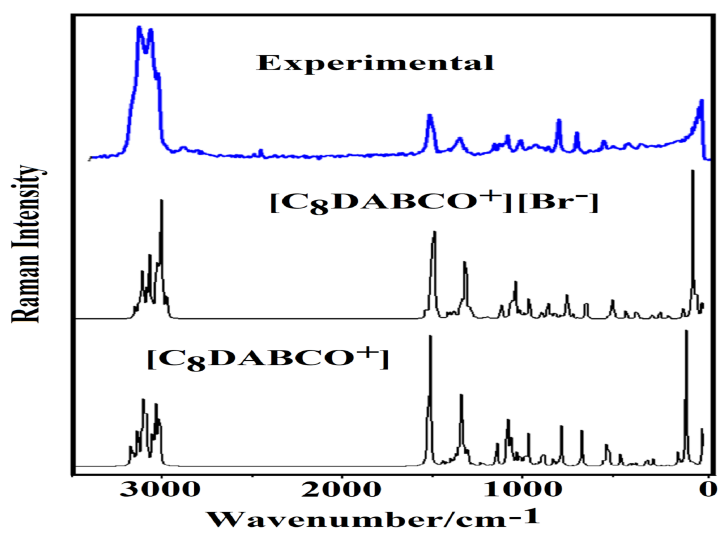

Figure 7. Experimental FT-Raman of $\left[\mathrm{C}_{8} \mathrm{DABCO}^{+}\right]$ $\left[\mathrm{Br}^{-}\right]$ionic liquid in the solid phase compared with the corresponding predicted for IL and cation in gas phase by using the hybrid B3LYP/6-31G* method.

As was explained in section computational details, two harmonic force fields were used to perform the vibrational assignments of cation. In a case, the definition of rings can be seen in Figure 1 from two different positions of cage-like structure. In the other case, only the deformations of these rings were considered as normal internal coordinates. Both harmonic force fields were obtained with the scaled quantum mechanical force field (SQMFF) methodology and the Molvib program using the normal internal coordinates and transferable scaling factors [29-31]. For both species, the better force fields were obtained with the normal internal coordinates of second case taking potential energy distribution (PED) contributions between 8 and $10 \%$. When the normal internal coordinates of rings were considered (three deformations and three torsions of rings) after of apply the SQM methodology some coordinates disappears and, for these reasons, the total of coordinates of IL and its cation are not observed. In Table 5 are presented observed and calculated wavenumbers for $\left[\mathrm{C}_{8} \mathrm{DABCO}^{+}\right]\left[\mathrm{Br}^{-}\right]$ionic liquid and its cation in gas phase by using B3LYP/6-31G* calculations together with the corresponding assignments. After that, assignments for some important groups are discussed below.

Table 5. Observed and calculated wavenumbers $\left(\mathrm{cm}^{-1}\right)$ and assignments for $\left[\mathrm{C}_{8} \mathrm{DABCO} \mathrm{C}^{+}\right]\left[\mathrm{Br}^{-}\right]$ionic liquid and its cation in gas phase by using the hybrid B3LYP Method.

\begin{tabular}{llll}
\hline \multicolumn{2}{c}{ Experimental } & \multicolumn{3}{c}{ B3LYP/6-31G* Method } \\
\hline IR $\quad$ Raman & {$\left[\mathrm{C}_{8} \mathrm{DABCO}^{+}\right]$} & {$\left[\mathrm{C}_{8} \mathrm{DABCO}+\left[\mathrm{Br}^{-}\right]\right.$} \\
\cline { 2 - 4 }
\end{tabular}




\begin{tabular}{|c|c|c|c|c|c|}
\hline & & $\mathrm{SQM}^{\mathrm{c}}$ & Assignments $^{\mathrm{a}}$ & $\mathrm{SQM}^{\mathrm{d}}$ & Assignments $^{\mathrm{a}}$ \\
\hline \multicolumn{2}{|l|}{$2953 \mathrm{sh}$} & 3046 & $v_{\mathrm{a}} \mathrm{CH}_{2}(\mathrm{C} 7)$ & 3027 & $v_{\mathrm{a}} \mathrm{CH}_{2}(\mathrm{C} 7)$ \\
\hline \multirow[t]{17}{*}{ 2936sh } & & 3042 & $v_{\mathrm{a}} \mathrm{CH}_{2}(\mathrm{C} 6)$ & 3012 & $v_{\mathrm{a}} \mathrm{CH}_{2}(\mathrm{C} 6)$ \\
\hline & & 3031 & $v_{\mathrm{a}} \mathrm{CH}_{2}(\mathrm{C} 5)$ & 2999 & $v_{\mathrm{a}} \mathrm{CH}_{2}(\mathrm{C} 2)$ \\
\hline & & 3011 & $v_{\mathrm{a}} \mathrm{CH}_{2}(\mathrm{C} 20)$ & 2993 & $v_{\mathrm{a}} \mathrm{CH}_{2}(\mathrm{C} 3)$ \\
\hline & & 3011 & $v_{\mathrm{a}} \mathrm{CH}_{2}(\mathrm{C} 3)$ & 2988 & $v_{\mathrm{a}} \mathrm{CH}_{2}(\mathrm{C} 4)$ \\
\hline & & 3009 & $v_{\mathrm{a}} \mathrm{CH}_{2}(\mathrm{C} 4)$ & 2987 & $v_{\mathrm{a}} \mathrm{CH}_{2}(\mathrm{C} 5)$ \\
\hline & & 3007 & $v_{\mathrm{a}} \mathrm{CH}_{2}(\mathrm{C} 2)$ & 2983 & $v_{\mathrm{a}} \mathrm{CH}_{3}$ \\
\hline & & 2992 & $v_{\mathrm{a}} \mathrm{CH}_{3}$ & 2980 & $v_{\mathrm{a}} \mathrm{CH}_{2}(\mathrm{C} 24)$ \\
\hline & & 2982 & $v_{\mathrm{a}} \mathrm{CH}_{3}$ & 2977 & $v_{\mathrm{a}} \mathrm{CH}_{3}$ \\
\hline & & 2981 & $v_{\mathrm{s}} \mathrm{CH}_{2}(\mathrm{C} 7)$ & 2965 & $v_{\mathrm{s}} \mathrm{CH}_{2}(\mathrm{C} 7)$ \\
\hline & & 2980 & $v_{\mathrm{s}} \mathrm{CH}_{2}(\mathrm{C} 6)$ & 2964 & $v_{\mathrm{a}} \mathrm{CH}_{2}(\mathrm{C} 20)$ \\
\hline & & 2975 & $v_{\mathrm{a}} \mathrm{CH}_{2}(\mathrm{C} 24)$ & 2953 & $v_{\mathrm{a}} \mathrm{CH}_{2}(\mathrm{C} 27)$ \\
\hline & & 2973 & $v_{\mathrm{s}} \mathrm{CH}_{2}(\mathrm{C} 5)$ & 2950 & $v_{\mathrm{s}} \mathrm{CH}_{2}(\mathrm{C} 3)$ \\
\hline & & 2969 & $v_{\mathrm{s}} \mathrm{CH}_{2}(\mathrm{C} 3) v_{\mathrm{s}} \mathrm{CH}_{2}(\mathrm{C} 4)$ & 2947 & $v_{\mathrm{s}} \mathrm{CH}_{2}(\mathrm{C} 4)$ \\
\hline & & 2966 & $v_{\mathrm{s}} \mathrm{CH}_{2}(\mathrm{C} 3)$ & 2944 & $v_{\mathrm{a}} \mathrm{CH}_{2}(\mathrm{C} 33)$ \\
\hline & 2936vs & 2965 & $v_{\mathrm{s}} \mathrm{CH}_{2}(\mathrm{C} 4) v_{\mathrm{s}} \mathrm{CH}_{2}(\mathrm{C} 2)$ & 2944 & $v_{\mathrm{s}} \mathrm{CH}_{2}(\mathrm{C} 2)$ \\
\hline & & 2956 & $v_{\mathrm{s}} \mathrm{CH}_{2}(\mathrm{C} 20)$ & 2931 & $v_{\mathrm{a}} \mathrm{CH}_{2}(\mathrm{C} 39)$ \\
\hline & 2922sh & 2954 & $v_{\mathrm{a}} \mathrm{CH}_{2}(\mathrm{C} 30) v_{\mathrm{a}} \mathrm{CH}_{2}(\mathrm{C} 33)$ & 2918 & $v_{\mathrm{a}} \mathrm{CH}_{2}(\mathrm{C} 30)$ \\
\hline \multirow[t]{7}{*}{$2918 \mathrm{~s}$} & & 2943 & $v_{\mathrm{a}} \mathrm{CH}_{2}(\mathrm{C} 27)$ & 2916 & $v_{\mathrm{s}} \mathrm{CH}_{3}$ \\
\hline & & 2934 & $v_{\mathrm{s}} \mathrm{CH}_{2}(\mathrm{C} 24)$ & 2913 & $v_{\mathrm{s}} \mathrm{CH}_{2}(\mathrm{C} 24)$ \\
\hline & & 2931 & $v_{\mathrm{a}} \mathrm{CH}_{2}(\mathrm{C} 39)$ & 2911 & $v_{\mathrm{a}} \mathrm{CH}_{2}(\mathrm{C} 36)$ \\
\hline & & 2921 & $v_{\mathrm{s}} \mathrm{CH}_{3}$ & 2903 & $v_{\mathrm{s}} \mathrm{CH}_{2}(\mathrm{C} 39)$ \\
\hline & & 2920 & $v_{\mathrm{a}} \mathrm{CH}_{2}(\mathrm{C} 30)$ & 2900 & $v_{\mathrm{s}} \mathrm{CH}_{2}(\mathrm{C} 27)$ \\
\hline & & 2913 & $v_{\mathrm{a}} \mathrm{CH}_{2}(\mathrm{C} 36) v_{\mathrm{a}} \mathrm{CH}_{2}(\mathrm{C} 33)$ & 2895 & $v_{\mathrm{s}} \mathrm{CH}_{2}(\mathrm{C} 33)$ \\
\hline & & 2910 & $v_{\mathrm{s}} \mathrm{CH}_{2}(\mathrm{C} 27)$ & 2889 & $v_{\mathrm{s}} \mathrm{CH}_{2}(\mathrm{C} 30)$ \\
\hline \multirow[t]{2}{*}{$2904 \mathrm{sh}$} & & 2905 & $v_{\mathrm{s}} \mathrm{CH}_{2}(\mathrm{C} 39)$ & 2887 & $v_{\mathrm{s}} \mathrm{CH}_{2}(\mathrm{C} 36)$ \\
\hline & 2876vs & 2899 & $v_{\mathrm{s}} \mathrm{CH}_{2}(\mathrm{C} 30)$ & 2886 & $v_{\mathrm{s}} \mathrm{CH}_{2}(\mathrm{C} 20) v_{\mathrm{s}} \mathrm{CH}_{2}(\mathrm{C} 5)$ \\
\hline $2887 \mathrm{sh}$ & $2866 \mathrm{sh}$ & 2894 & $v_{\mathrm{s}} \mathrm{CH}_{2}(\mathrm{C} 33)$ & 2862 & $v_{\mathrm{s}} \mathrm{CH}_{2}(\mathrm{C} 20)$ \\
\hline $2855 \mathrm{~m}$ & $2845 \mathrm{sh}$ & 2891 & $v_{\mathrm{s}} \mathrm{CH}_{2}(\mathrm{C} 36)$ & 2858 & $v_{\mathrm{s}} \mathrm{CH}_{2}(\mathrm{C} 6) v_{\mathrm{s}} \mathrm{CH}_{2}(\mathrm{C} 5)$ \\
\hline $1727 w$ & & 1486 & $\delta \mathrm{CH}_{2}(\mathrm{C} 5)$ & 1499 & wagCH ${ }_{2}(\mathrm{C} 20)$ \\
\hline $1622 w$ & $1474 \mathrm{sh}$ & 1476 & $\delta \mathrm{CH}_{2}(\mathrm{C} 39) \delta \mathrm{CH}_{2}(\mathrm{C} 36)$ & 1476 & $\delta \mathrm{CH}_{2}(\mathrm{C} 2)$ \\
\hline $1484 \mathrm{sh}$ & & 1472 & $\delta_{\mathrm{a}} \mathrm{CH}_{3}$ & 1475 & $\delta_{\mathrm{a}} \mathrm{CH}_{3} \delta \mathrm{CH}_{2}(\mathrm{C} 39)$ \\
\hline \multirow[t]{4}{*}{$1475 \mathrm{sh}$} & & 1468 & $\delta \mathrm{CH}_{2}(\mathrm{C} 3)$ & 1471 & $\delta_{\mathrm{a}} \mathrm{CH}_{3} \delta \mathrm{CH}_{2}(\mathrm{C} 27)$ \\
\hline & & 1465 & $\delta_{\mathrm{a}} \mathrm{CH}_{3}$ & 1468 & $\delta \mathrm{CH}_{2}(\mathrm{C} 5)$ \\
\hline & & 1464 & $\delta \mathrm{CH}_{2}(\mathrm{C} 24)$ & 1465 & $\delta \mathrm{CH}_{2}(\mathrm{C} 7)$ \\
\hline & & 1460 & $\delta \mathrm{CH}_{2}(\mathrm{C} 5) \delta \mathrm{CH}_{2}(\mathrm{C} 6)$ & 1464 & $\delta_{\mathrm{a}} \mathrm{CH}_{3}$ \\
\hline \multirow[t]{6}{*}{$1458 \mathrm{~s}$} & & 1459 & $\delta \mathrm{CH}_{2}(\mathrm{C} 7)$ & 1463 & $\delta \mathrm{CH}_{2}(\mathrm{C} 24)$ \\
\hline & & 1457 & $\delta \mathrm{CH}_{2}(\mathrm{C} 30) \delta \mathrm{CH}_{2}(\mathrm{C} 39)$ & 1459 & $\delta \mathrm{CH}_{2}(\mathrm{C} 6)$ \\
\hline & & 1451 & $\delta \mathrm{CH}_{2}(\mathrm{C} 27) \delta \mathrm{CH}_{2}(\mathrm{C} 39)$ & 1455 & $\delta \mathrm{CH}_{2}(\mathrm{C} 39) \delta \mathrm{CH}_{2}(\mathrm{C} 30)$ \\
\hline & & 1451 & $\delta \mathrm{CH}_{2}(\mathrm{C} 6) \delta \mathrm{CH}_{2}(\mathrm{C} 2)$ & 1453 & $\delta \mathrm{CH}_{2}(\mathrm{C} 4)$ \\
\hline & & 1449 & $\delta \mathrm{CH}_{2}(\mathrm{C} 4)$ & 1450 & $\delta \mathrm{CH}_{2}(\mathrm{C} 27) \delta \mathrm{CH}_{2}(\mathrm{C} 5)$ \\
\hline & $1448 \mathrm{~s}$ & 1448 & $\delta \mathrm{CH}_{2}(\mathrm{C} 33)$ & 1448 & $\delta \mathrm{CH}_{2}(\mathrm{C} 36)$ \\
\hline $1446 \mathrm{sh}$ & & 1447 & $\delta \mathrm{CH}_{2}(\mathrm{C} 30) \delta \mathrm{CH}_{2}(\mathrm{C} 36)$ & 1447 & $\delta \mathrm{CH}_{2}(\mathrm{C} 33)$ \\
\hline \multirow[t]{2}{*}{1434 sh } & & 1442 & $\delta \mathrm{CH}_{2}(\mathrm{C} 20)$ & 1446 & $\delta \mathrm{CH}_{2}(\mathrm{C} 20)$ \\
\hline & & 1423 & wagCH $_{2}(\mathrm{C} 20)$ & 1445 & $\delta \mathrm{CH}_{2}(\mathrm{C} 3)$ \\
\hline \multirow[t]{2}{*}{$1411 w$} & $1418 \mathrm{sh}$ & 1406 & wagCH ${ }_{2}(\mathrm{C} 33)$ wagCH $\mathrm{F}_{2}(\mathrm{C} 36)$ & 1417 & wagCH $(\mathrm{C} 6)$ \\
\hline & 1409sh & 1401 & wagCH ${ }_{2}(\mathrm{C} 27)$ wagCH $_{2}(\mathrm{C} 30)$ & 1407 & wagCH$_{2}(\mathrm{C} 30)$ wagCH $2(\mathrm{C} 33)$ \\
\hline 1392sh & & 1397 & wagCH $(\mathrm{C} 6)$ & 1404 & $\mathrm{wagCH}_{2}(\mathrm{C} 36) \mathrm{wagCH}_{2}(\mathrm{C} 27)$ \\
\hline
\end{tabular}




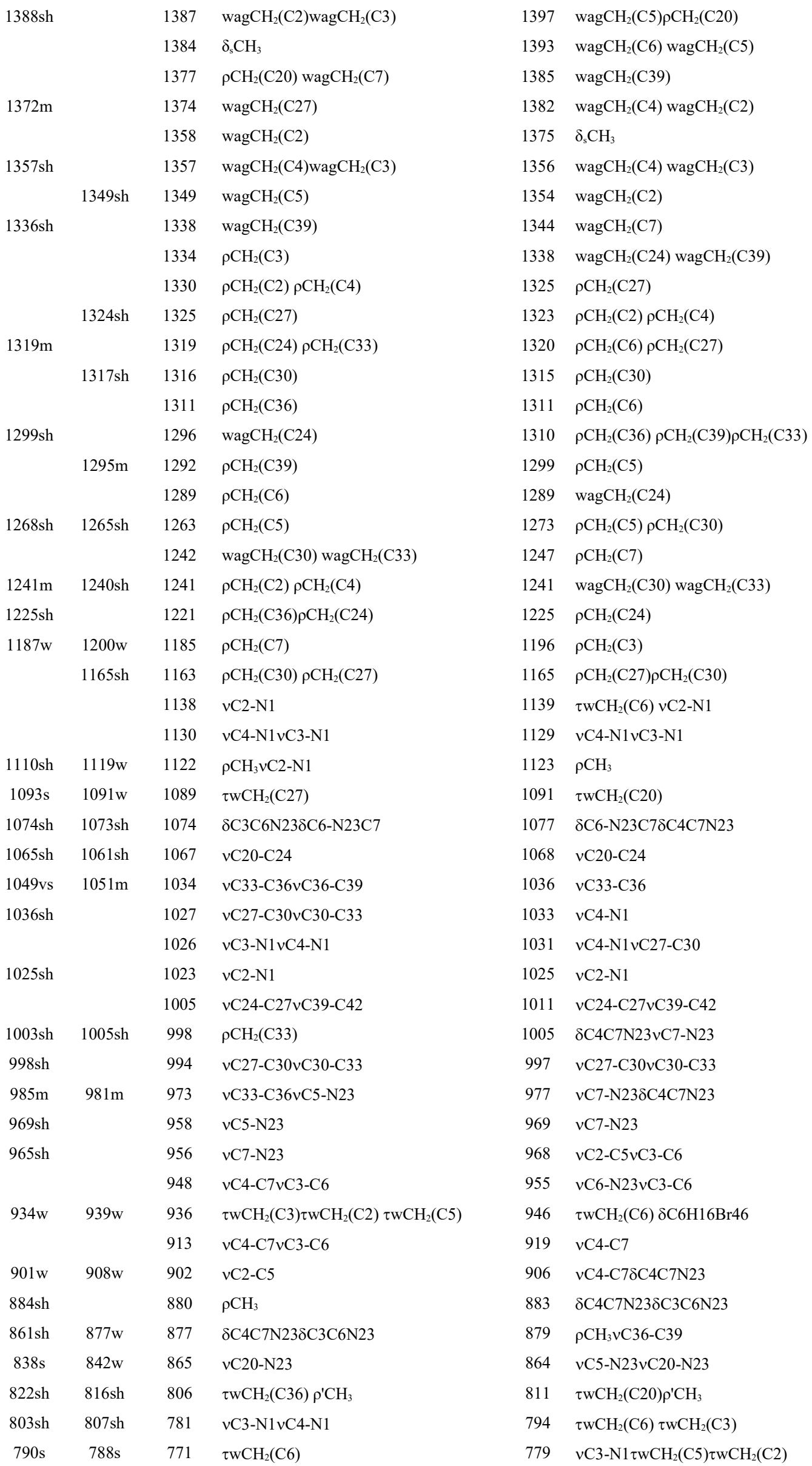




\begin{tabular}{|c|c|c|c|c|c|}
\hline $774 \mathrm{sh}$ & & 770 & $\tau \mathrm{wCH}_{2}(\mathrm{C} 7)$ & 776 & $v \mathrm{C} 2-\mathrm{N} 1 v \mathrm{C} 4-\mathrm{N} 1$ \\
\hline $732 \mathrm{sh}$ & 739sh & 740 & $\tau \mathrm{wCH}{ }_{2}(\mathrm{C} 4)$ & 747 & $\tau \mathrm{wCH}_{2}(\mathrm{C} 4) \tau \mathrm{wCH}_{2}(\mathrm{C} 7)$ \\
\hline $720 w$ & $716 \mathrm{sh}$ & 732 & $\tau \mathrm{wCH}{ }_{2}(\mathrm{C} 39) \tau \mathrm{wCH} \mathrm{H}_{2}(\mathrm{C} 20)$ & 739 & $\tau \mathrm{wCH}(\mathrm{C} 20) \tau \mathrm{wCH}_{2}(\mathrm{C} 39)$ \\
\hline \multirow[t]{3}{*}{$696 \mathrm{~m}$} & $697 \mathrm{~m}$ & 689 & $\tau \mathrm{wCH}_{2}(\mathrm{C} 24)$ & 695 & $\tau \mathrm{wCH}{ }_{2}(\mathrm{C} 24) \tau \mathrm{wCH} \mathrm{H}_{2}(\mathrm{C} 39)$ \\
\hline & & 681 & vC6-N23 & 685 & vC6-N23 \\
\hline & $676 \mathrm{sh}$ & 668 & $\tau \mathrm{wCH}_{2}(\mathrm{C} 27)$ & 671 & $\tau \mathrm{wCH}_{2}(\mathrm{C} 27)$ \\
\hline \multirow[t]{29}{*}{$666 w$} & $631 w$ & 662 & $\tau \mathrm{wCH}_{2}(\mathrm{C} 33) \tau \mathrm{wCH} \mathrm{W}_{2}(\mathrm{C} 30)$ & 662 & $\tau \mathrm{wCH}_{2}(\mathrm{C} 33) \tau \mathrm{wCH}_{2}(\mathrm{C} 36)$ \\
\hline & $598 \mathrm{w}$ & 583 & $\delta \mathrm{C} 2 \mathrm{C} 5 \mathrm{~N} 23$ & 588 & $\delta \mathrm{C} 2 \mathrm{C} 5 \mathrm{~N} 23$ \\
\hline & $560 \mathrm{w}$ & 563 & $\delta \mathrm{C} 4 \mathrm{C} 7 \mathrm{~N} 23$ & 565 & $8 \mathrm{C} 4 \mathrm{C} 7 \mathrm{~N} 23$ \\
\hline & $560 \mathrm{w}$ & 554 & $8 \mathrm{C} 3 \mathrm{C} 6 \mathrm{~N} 23$ & 560 & $8 \mathrm{C} 3 \mathrm{C} 6 \mathrm{~N} 23$ \\
\hline & $513 \mathrm{w}$ & 497 & $\delta \mathrm{C} 24 \mathrm{C} 27 \mathrm{C} 30 \delta \mathrm{C} 33 \mathrm{C} 36 \mathrm{C} 39$ & 500 & $\delta \mathrm{C} 24 \mathrm{C} 27 \mathrm{C} 30 \delta \mathrm{C} 24 \mathrm{C} 20 \mathrm{~N} 23$ \\
\hline & $454 \mathrm{sh}$ & 453 & $8 \mathrm{C} 36 \mathrm{C} 39 \mathrm{C} 42$ & 455 & $8 \mathrm{C} 36 \mathrm{C} 39 \mathrm{C} 428 \mathrm{C} 27 \mathrm{C} 30 \mathrm{C} 33$ \\
\hline & $431 \mathrm{w}$ & 432 & $\delta \mathrm{C} 5 \mathrm{~N} 23 \mathrm{C} 68 \mathrm{C} 5 \mathrm{~N} 23 \mathrm{C} 7$ & 442 & $\delta \mathrm{C} 5 \mathrm{~N} 23 \mathrm{C} 6$ \\
\hline & $414 \mathrm{sh}$ & 421 & $\delta \mathrm{C} 6-\mathrm{N} 23 \mathrm{C} 78 \mathrm{C} 4 \mathrm{~N} 1 \mathrm{C} 3$ & 422 & $8 \mathrm{C} 6-\mathrm{N} 23 \mathrm{C} 7$ \\
\hline & $370 w$ & 373 & $\delta \mathrm{C} 4 \mathrm{~N} 1 \mathrm{C} 3 \rho \mathrm{N} 23-\mathrm{C} 24$ & 375 & $\delta \mathrm{C} 3 \mathrm{~N} 1 \mathrm{C} 2 \rho^{\prime} \mathrm{N} 23-\mathrm{C} 24$ \\
\hline & & 364 & $\rho^{\prime} \mathrm{N} 23-\mathrm{C} 24 \delta \mathrm{C} 4 \mathrm{~N} 1 \mathrm{C} 2 \delta \mathrm{C} 3 \mathrm{~N} 1 \mathrm{C} 2$ & 369 & $\delta \mathrm{C} 4 \mathrm{~N} 1 \mathrm{C} 2$ \\
\hline & $346 \mathrm{sh}$ & 338 & $\delta \mathrm{C} 36 \mathrm{C} 39 \mathrm{C} 428 \mathrm{C} 5 \mathrm{~N} 23 \mathrm{C} 7$ & 338 & $\delta \mathrm{C} 4 \mathrm{~N} 1 \mathrm{C} 3$ \\
\hline & $314 \mathrm{sh}$ & 296 & $8 \mathrm{C} 6-\mathrm{N} 23 \mathrm{C} 7$ & 309 & $\delta \mathrm{C} 6-\mathrm{N} 23 \mathrm{C} 7 \delta \mathrm{C} 6 \mathrm{H} 16 \mathrm{Br} 46$ \\
\hline & $276 w$ & 265 & $8 \mathrm{C} 5 \mathrm{~N} 23 \mathrm{C} 68 \mathrm{C} 5 \mathrm{~N} 23 \mathrm{C} 7$ & 294 & $8 \mathrm{C} 5 \mathrm{~N} 23 \mathrm{C} 7$ \\
\hline & $236 \mathrm{sh}$ & 223 & $\tau \mathrm{wCH}_{3}$ & 223 & $\rho \mathrm{N} 23-\mathrm{C} 24 \delta \mathrm{C} 33 \mathrm{C} 36 \mathrm{C} 39$ \\
\hline & $217 \mathrm{sh}$ & 214 & $\rho \mathrm{N} 23-\mathrm{C} 24$ & 221 & $\tau \mathrm{wCH}_{3}$ \\
\hline & $175 \mathrm{sh}$ & 166 & $\delta \mathrm{C} 20 \mathrm{C} 24 \mathrm{C} 27 \mathrm{vC} 20-\mathrm{N} 23$ & 168 & $\delta \mathrm{C} 20 \mathrm{C} 24 \mathrm{C} 27$ \\
\hline & $154 \mathrm{sh}$ & & & 159 & $\tau \mathrm{C} 27-\mathrm{C} 24$ \\
\hline & & 150 & $\tau \mathrm{C} 33-\mathrm{C} 30$ & 151 & $\delta \mathrm{C} 6 \mathrm{H} 16 \mathrm{Br} 46$ \\
\hline & $137 \mathrm{sh}$ & 136 & $\tau \mathrm{C} 30-\mathrm{C} 27$ & 137 & $\tau \mathrm{C} 33-\mathrm{C} 30 \tau \mathrm{C} 39-\mathrm{C} 36$ \\
\hline & $118 \mathrm{sh}$ & & & 131 & $\tau \mathrm{C} 30-\mathrm{C} 27 \tau \mathrm{C} 36-\mathrm{C} 33$ \\
\hline & $107 \mathrm{sh}$ & 116 & $\tau \mathrm{C} 39-\mathrm{C} 36$ & 107 & $8 \mathrm{C} 30 \mathrm{C} 33 \mathrm{C} 36$ \\
\hline & $93 \mathrm{sh}$ & 115 & $8 \mathrm{C} 33 \mathrm{C} 36 \mathrm{C} 398 \mathrm{C} 30 \mathrm{C} 33 \mathrm{C} 368 \mathrm{C} 24 \mathrm{C} 20 \mathrm{~N} 23$ & 102 & $v \mathrm{H} 16-\mathrm{Br} 46$ \\
\hline & $84 \mathrm{sh}$ & 84 & $\tau \mathrm{C} 36-\mathrm{C} 33$ & 82 & $\tau_{\mathrm{w}} \mathrm{C} 20-\mathrm{N} 23 \tau \mathrm{C} 39-\mathrm{C} 36$ \\
\hline & $74 \mathrm{sh}$ & 69 & $\tau \mathrm{C} 36-\mathrm{C} 33 \tau \mathrm{C} 24-\mathrm{C} 20$ & 70 & $\tau \mathrm{C} 36-\mathrm{C} 33 \tau \mathrm{C} 24-\mathrm{C} 20$ \\
\hline & $57 \mathrm{vs}$ & 58 & $\tau_{\mathrm{w}} \mathrm{C} 20-\mathrm{N} 23$ & 50 & $\tau \mathrm{C} 6-\mathrm{H} 16 \delta \mathrm{C} 6 \mathrm{H} 16 \mathrm{Br} 46$ \\
\hline & $45 \mathrm{sh}$ & 43 & $8 \mathrm{C} 24 \mathrm{C} 27 \mathrm{C} 30 \delta \mathrm{C} 27 \mathrm{C} 30 \mathrm{C} 338 \mathrm{C} 20 \mathrm{C} 24 \mathrm{C} 27$ & 39 & $\tau \mathrm{C} 6-\mathrm{H} 16$ \\
\hline & $38 \mathrm{sh}$ & 35 & $\tau_{\mathrm{w}} \mathrm{C} 20-\mathrm{N} 23 \tau \mathrm{C} 24-\mathrm{C} 20$ & 34 & $\tau \mathrm{C} 6-\mathrm{H} 16 \delta \mathrm{C} 20 \mathrm{C} 24 \mathrm{C} 27$ \\
\hline & & 26 & $\tau \mathrm{C} 24-\mathrm{C} 20 \tau \mathrm{C} 27-\mathrm{C} 24$ & 28 & $\tau_{\mathrm{w}} \mathrm{C} 20-\mathrm{N} 23$ \\
\hline & & & & 14 & $\tau \mathrm{C} 24-\mathrm{C} 20$ \\
\hline
\end{tabular}

Abbreviations: $v$, stretching; $\beta$, deformation in the plane; $\gamma$, deformation out of plane; wag, wagging; $\tau$, torsion;

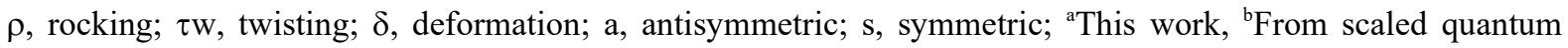
mechanics force field with B3LYP/6-31G* method, ${ }^{\mathrm{c}}$ From scaled quantum mechanics force field with B3LYP/6-31G* method; ' ${ }^{*}$ rom B3LYP/6-31G* method.

\subsubsection{Assignments $\mathrm{C}-\mathrm{H}$ groups.}

3.6.1.1. $\mathrm{CH}_{3}$ modes. The presence of $\mathrm{Br}$ anion shifts the antisymmetric and symmetric stretching modes of this group at lower wavenumbers than the corresponding to cation. Thus, 
these modes are predicted in the cation at 2992, 2982 and $2966 \mathrm{~cm}^{-1}$ while in the IL at 2983, 2977 and $2916 \mathrm{~cm}^{-1}$. Hence, the shoulders and intense IR and Raman bands observed in these regions are assigned to these groups. Here, the strong Raman bands are clearly assigned to symmetrical modes of these groups. In both species, the $\mathrm{CH}_{3}$ deformation modes are assigned between 1475 and $1375 \mathrm{~cm}^{-1}$ in accordance with the calculations but in the IL the antisymmetric modes are coupled while the rocking and twisting modes for the two species are predicted in the $1123 / 879$ and $223 / 221 \mathrm{~cm}^{-1}$ regions and, therefore, they were assigned as predicted by SQM calculations and, as detailed $\mathrm{n}$ Table 5 .

3.6.1.2. $\mathrm{CH}_{2}$ modes. There are seven $\mathrm{CH}_{2}$ groups in the side chains of cation and IL while six groups are present in three rings of both species. The SQM calculations predict few vibration modes of these groups in approximately the same positions while in general, the presence of $\mathrm{Br}$ generates changes in the positions and intensities of some bands corresponding to IL. The antisymmetric and symmetric modes are predicted between 3046 and $2858 \mathrm{~cm}^{-1}$, therefore, the IR and Raman bands observed in these regions can be assigned to these vibration modes. The $\mathrm{CH}_{2}$ deformation, waging, rocking, and twisting modes for the IL are predicted at higher wavenumbers than the cation, in the $1499 / 1446,1423 / 1338,1397 / 1163$ and $1139 / 662 \mathrm{~cm}^{-1}$ regions. Consequently, all those vibration modes are assigned in the predicted regions by the B3LYP/6-31G* calculations, as can be seen in Table 5 .

3.6.1.3. Skeletal modes. The two species, cation and IL present two different $\mathrm{C}-\mathrm{N}$ stretching modes, where three of them are those related to C-N1 stretching modes (N1 tertiary amine) and the other ones related to $\mathrm{C}-\mathrm{N} 23$ stretching modes (ammonium cation with a charged nitrogen center). The SQM calculations predicted the C-N1 stretching modes in approximately the same positions for both species while the other C-N23 stretching modes are observed in the IL at higher wavenumbers due to Br anion and to positively charged N23 atom. Also, some C-C stretching modes are predicted in different positions in both species, for which they are assigned in the regions predicted by SQM/B3LYP/6-31G*. Hence, the CC stretching modes were assigned between 1068 and $902 \mathrm{~cm}^{-1}$, as predicted by the SQM calculations and, as observed in Table 5. Note that in Table 5 the deformation and torsion ring modes are not observed because some of these coordinates disappear when the SQM methodology are applied for the two species and, for these reasons, the second harmonic force fields where for both species only were considered deformations of rings.

\subsection{Force fields}


The scaled force constants for the $\left[\mathrm{C}_{8} \mathrm{DABCO}{ }^{+}\right]\left[\mathrm{Br}^{-}\right] \mathrm{IL}$ and its cation have been calculated from the corresponding harmonic force fields because these parameters can explain the forces of different bonds [29-31]. Hence, these constants computed in gas phase by using the B3LYP/6-31G* method are presented in Table 6 compared with reported for [Aliquat $\left.{ }^{+}\right]\left[\mathrm{Cl}^{-}\right]$ and [BMIM][OTF] ILs by using the same method but different basis set.

Table 6. Scaled internal force constants for the $\left[\mathrm{C}_{8} \mathrm{DABCO}{ }^{+}\right]\left[\mathrm{Br}^{-}\right]$IL and its cation in gas phase compared with reported for $\left[\right.$ Aliquat $\left.{ }^{+}\right]\left[\mathrm{Cl}^{-}\right]$and $[\mathrm{BMIM}][\mathrm{OTF}]$ IL by using the B3LYP method and different basis sets.

\begin{tabular}{|c|c|c|c|c|c|c|}
\hline \multicolumn{7}{|c|}{ B3LYP method } \\
\hline \multirow{2}{*}{$\begin{array}{c}\text { Force } \\
\text { constants }\end{array}$} & \multicolumn{4}{|c|}{$6-31 \mathrm{G}^{*}$} & \multicolumn{2}{|c|}{$6-311++\mathrm{G}^{* *}$} \\
\hline & {$\left[\mathrm{C}_{8} \mathrm{DABCO}^{+}\right]^{\mathrm{a}}$} & {$\left[\mathrm{C}_{8} \mathrm{DABCO}^{+}\right]\left[\mathrm{Br}^{-}\right]^{\mathrm{a}}$} & {$\left[\right.$ Aliquat $\left.^{+}\right]\left[\mathrm{Cl}^{-}\right]^{\mathrm{b}}$} & [Aliquat $\left.^{+}\right]^{\mathrm{b}}$ & {$[\mathrm{BMIM}]^{\mathrm{c}}$} & {$[\mathrm{BMIM}][\mathrm{OTF}]^{\mathrm{c}}$} \\
\hline$f\left(v N-C_{3}\right)$ & 7.40 & 7.38 & & & & \\
\hline$f\left(v N-C_{4}\right)$ & 5.87 & 6.00 & 2.45 & 3.49 & & \\
\hline$f\left(v \mathrm{CH}_{2}\right)$ & 4.84 & 4.78 & 4.73 & 4.75 & 4.73 & 4.73 \\
\hline$f\left(v C H_{3}\right)$ & 4.85 & 4.83 & 4.85 & 4.91 & 4.87 & 4.84 \\
\hline$f\left(\delta \mathrm{CH}_{2}\right)$ & 0.87 & 0.88 & 0.81 & 0.79 & 0.77 & 1.28 \\
\hline$f\left(\delta \mathrm{CH}_{3}\right)$ & 0.56 & 0.56 & 0.56 & 0.56 & 0.52 & 0.54 \\
\hline
\end{tabular}

Units are mdyn $\AA^{-1}$ for stretching and mdyn $\AA$ rad $^{-2}$ for angle deformations. ${ }^{a}$ This work, ${ }^{b}$ From Ref [27] for [Aliquat $\left.{ }^{+}\right]\left[\mathrm{Cl}^{-}\right]$, ${ }^{\mathrm{c}}$ From $\operatorname{Ref}[25]$ for $[\mathrm{BMIM}][\mathrm{OTF}]$.

Here, a interesting comparison are the $f\left(v N-C_{3}\right)$ and $f\left(v N-C_{4}\right)$ force constants of $\left[\mathrm{C}_{8} \mathrm{DABCO}^{+}\right]$ [Br-] IL and its cation due to the different characteristics of seven $\mathrm{C}-\mathrm{N}$ bonds because three of them are related to $\mathrm{C}-\mathrm{N} 1$ bonds where $\mathrm{N} 1$ is tertiary amine and the other ones related to $\mathrm{C}$ N23 bonds where N23 is ammonium cation positively charged. These results show no differences in the values of both species but between $f\left(v N-C_{3}\right)$ and $f\left(v N-C_{4}\right)$ force constants. As expected, the $f\left(v N-C_{3}\right)$ force constants have higher values than the other ones because they only take into account three bonds while the others consider four bonds. Another interesting results are observed when the $f\left(v N-C_{4}\right)$ force constants of $\left[\mathrm{C}_{8} \mathrm{DABCO}^{+}\right]\left[\mathrm{Br}^{-}\right] \mathrm{IL}$ and its cation are compared with reported for $\left[\mathrm{Aliquat}^{+}\right]\left[\mathrm{Cl}^{-}\right]$and its cation [27]. We observed very low values for the latter IL because the presence of $\mathrm{Cl}$ anion, most electronegative than $\mathrm{Br}$, reduces notably the value of 3.49 in the cation to 2.45 in the IL. Obviously, the large side chains in $\left[\mathrm{Aliquat}^{+}\right]\left[\mathrm{Cl}^{-}\right]$and its cation also have influence in their values. The other force constants corresponding to the $\mathrm{CH}_{2}$ and $\mathrm{CH}_{3}$ groups present practically the same values in the two species indicating that few influences has the $\mathrm{Br}$ anion on the force constants values. Note that in the 1-butyl-3-methylimidazolium trifluoromethanesulfonate IL, the $f\left(\delta \mathrm{CH}_{2}\right)$ force constant is high due to that this IL the cation and the anion have bidentate coordination modes where one $\mathrm{H}$ atom of $\mathrm{CH}_{2}$ group is involved [25].

\section{Conclusions}


In the present work, a new DABCO-based ionic liquid, namely 1-octyl-1,4-diazabicyclo [2.2.2] octan-1-ium Bromide $\left(\left[\mathrm{C}_{8} \mathrm{DABCO}^{+}\right][\mathrm{Br}-]\right)$ has been synthesized through $\mathrm{N}$-alkylation of 1,4-diazabicyclo [2.2.2] octane with 1-bromooctane using a simple procedure in one step. The synthesized $\left[\mathrm{C}_{8} \mathrm{DABCO}{ }^{+}\right]\left[\mathrm{Br}^{-}\right]$IL was characterized by FT-IR, FT-Raman and by ${ }^{1} \mathrm{H}$ and ${ }^{13} \mathrm{C}-\mathrm{NMR}$ spectroscopies. The structure of $\left[\mathrm{C}_{8} \mathrm{DABCO}^{+}\right]\left[\mathrm{Br}^{-}\right] \mathrm{IL}$ was confirmed combining ${ }^{1} \mathrm{H}$ and ${ }^{13} \mathrm{C}$-NMR spectroscopies with B3LYP/6-31G* calculations. Three ionic $\mathrm{C}-\mathrm{H} \cdots \mathrm{Br}$ bonds were predicted by natural bond orbital (NBO), atoms in molecules (AIM) calculations and bond orders but a monodentate coordination between the $\left[\mathrm{C}_{8} \mathrm{DABCO}{ }^{+}\right]$cation and $\mathrm{Br}$ anion is suggested because only one of them has higher energy and lower distance. The effect of $\mathrm{Br}$ on properties of IL is clearly observed by the change in orientation and direction of dipole moment vector in the IL, as compared with the cation and by the MK charges and the MEPs values on all atoms corresponding to cage structure. NBO studies reveal that the $\mathrm{Br}$ anion strongly stabilizes to cation to form the IL. The complete vibrational assignments of 129 and 132 vibration modes expected for the cation and its IL were performed by using two harmonic force fields with the SQMFF methodology. The scaled harmonic force constants were also reported for both species.

The $\mathrm{Br}$ confers a higher reactivity to $\left[\mathrm{C}_{8} \mathrm{DABCO}{ }^{+}\right]\left[\mathrm{Br}^{-}\right]$, as suggested by analyses of frontier orbitals. The effect of $\mathrm{Br}$ is also observed in the different assignments observed for the IL and its cation. Reasonable correlations were found between the experimental IR, Raman and NMR spectra and the corresponding theoretical ones.

\section{ACKNOWLEDGEMENTS}

This work was supported with grants from financial support by The Ministry of Higher Education and Scientific Research (MESRS) of Algeria in PRFU project code: B00L01UN200120180002 and, from CIUNT Project N ${ }^{\text {o } 26 / D 608 ~(C o n s e j o ~ d e ~ I n v e s t i g a c i o n e s, ~}$ Universidad Nacional de Tucumán). The authors would like to thank Prof. Tom Sundius for his permission to use MOLVIB. (H.Boum.) gratefully acknowledge the efforts (BAKROU. H), (KHONATI S-M) and (Baraa A).

\section{Supporting Information Available: Tables S1-S5 and Figures S1-S4.}




\section{References}

[1] A. Turguła, K. Materna, D. Gwiazdowska, F. Walkiewicz, K. Marcinkowska, J. Pernak, Difunctional ammonium ionic liquids with bicyclic cations. New J. Chem., 43(11) (2019) 4477-4488.

[2] A. Ying, Z. Li, J. Yang, S. Liu, S. Xu, H. Yan, C. Wu, DABCO-based ionic liquids: recyclable catalysts for aza-Michael addition of $\alpha, \beta$-unsaturated amides under solvent-free conditions. J. Org. Chem., 79(14) (2014) 6510-6516.

[3] A. Ying, Y. Ni, S. Xu, S. Liu, J. Yang, R. Li, Novel DABCO based ionic liquids: green and efficient catalysts with dual catalytic roles for aqueous Knoevenagel condensation. Ind. Eng. Chem. Res., 53(14) (2014) 5678-5682.

[4] P. R. Boruah, M. J. Koiri, U. Bora, D. Sarma, A new recyclable/reusable ionic liquid/LiCl system for Suzuki-Miyaura cross coupling reactions. Tetrahedron Lett., 55(15) (2014) 24232425.

[5] J. Tong, L. S. Huang, D. Z. Xu, An efficient Friedel-Crafts alkylation for the synthesis of 3-indolyl-3-hydroxy oxindoles and unsymmetrical 3, 3-diaryl oxindoles catalyzed by Dabcobased ionic liquids in water. New J. Chem., 41(10) (2017) 3966-3974.

[6] D. K. Jangid, DABCO as a Base and an Organocatalyst in Organic Synthesis: A Review. Curr. Green Chem., 7(2) (2020) 146-162.

[7] Z. Z. Yang, L. N. He, Q. W. Song, K. H. Chen, A. H. Liu, X. M. Liu, Highly efficient $\mathrm{SO}_{2}$ absorption/activation and subsequent utilization by polyethylene glycol-functionalized Lewis basic ionic liquids. PCCP, 14(45) (2012) 15832-15839.

[8] H. Sahebi, E.Konoz, A. Ezabadi, A. Niazi, S. H. Ahmadi, Sensitive Determination of Imatinib Mesylate in Human Plasma Using DABCO-Based Ionic Liquid-Modified Magnetic Nanoparticles. Chromatographia, 83(8) (2020) 1009-1019.

[9] N. Seyyedi, F. Shirini, M. S. N. Langarudi, DABCO-based ionic liquids: green and recyclable catalysts for the synthesis of barbituric and thiobarbituric acid derivatives in aqueous media. RSC adv., 6(50) (2016) 44630-44640.

[10] Z. Z. Yang, L. N. He, C.X. Miao, S. Chanfreau, Lewis basic ionic liquids-catalyzed conversion of carbon dioxide to cyclic carbonates. ASC, 352(13) (2010) 2233-2240.

[11] F. Shirini, M. S. N. Langarudi, N. Daneshvar, N. Jamasbi, M. Irankhah-Khanghah, Preparation and characterization of [H2-DABCO][ClO4] 2 as a new member of DABCObased ionic liquids for the synthesis of pyrimido [4, 5-b]-quinoline and pyrimido [4, 5-d] pyrimidine derivatives. J. Mol. Struct, 1161 (2018) 366-382.

[12] A. Wykes, S. L. MacNeil, Synthesis of New lewis basic room-temperature ionic liquids by monoquaternization of 1,4-diazabicyclo [2.2. 2] octane (DABCO). Synlett, 2007(01) (2007) 0107-0110.

[13] P. Mondal, S. Chatterjee, P. Sarkar, A. Bhaumik, C. Mukhopadhyay, Preparation of DABCO-Based Acidic-Ionic-Liquid-Supported $\mathrm{ZnO}$ Nanoparticles and Their Application for Ecofriendly Synthesis of N-Aryl Polyhydroquinoline Derivatives. Chemistry Select., 4(40) (2019) 11701-11710.

[14] A. S. Nizovtsev, M. R. Ryzhikov, S. G. Kozlova, Structural flexibility of DABCO. Ab initio and DFT benchmark study. Chem. Phys. Lett., 667 (2017) 87-90. 
[15] S. G. Kozlova, S. P. Gabuda, Thermal properties of Zn2 (C8H4O4)2- C6H12N2 Metalorganic framework compound and mirror symmetry violation of dabco molecules. Sci. Rep, 7(1) (2017) 1-5.

[16] A.Ying, S. Li, X. Liu, J. Wang, Y. Liu, Z. Liu, Fabrication of DABCO functionalized poly (ionic liquids): Vital role of ferric oxides in the formation of mesoporous structure and used as highly efficient and recyclable catalysts for multi-component reactions. J. Catal, 391 (2020) 312-326.

[17] K. Zhang, K. J. Drummey, N. G. Moon, W. D. Chiang, T. E. Long, Styrenic DABCO salt-containing monomers for the synthesis of novel charged polymers. Polym. Chem, 7(20) (2016) 3370-3374.

[18] S. G. Kozlova, I. V. Mirzaeva, M. R. Ryzhikov, DABCO molecule in the $\mathrm{M}_{2}\left(\mathrm{C}_{8} \mathrm{H}_{4} \mathrm{O}_{4}\right)$ 2. $\mathrm{C}_{6} \mathrm{H}_{12} \mathrm{~N}_{2}(\mathrm{M}=\mathrm{Co}, \mathrm{Ni}, \mathrm{Cu}, \mathrm{Zn})$ metal-organic frameworks. Coord. Chem. Rev, 376 (2018) 62-74.

[19] J. R. McDivitt, G. L. Humphrey, Spectroscopic studies of the boron trihalide and borane complexes of 1, 4-diazabicyclo [2.2. 2] octane and quinuclidine. Spectrochim Acta A 30(4) (1974) 1021-1033.

[20] P. S. Santos, M. T. S. Mello, The Raman spectra of some molecular complexes of 1azabicyclo [2.2. 2] octane and 1, 4-diazabicyclo [2.2. 2] octane. J. Mol. Struct, 178 (1988) 121-133.

[21] M. T. Messina, P. Metrangolo, W. A. L. T. E. R. Navarrini, S. Radice, G. Resnati, G. Zerbi, Infrared and Raman analyses of the halogen-bonded non-covalent adducts formed by $\alpha$, $\omega$-diiodoperfluoroalkanes with DABCO and other electron donors. J. Mol. Struct, 524 (1-3) (2000) 87-94.

[22] V. I. Kovalenko, A. A. Akhmadiyarov, A. E. Vandyukov, A. R. Khamatgalimov, Experimental vibrational spectra and computational study of 1,4-diazabicyclo [2.2. 2] octane. J. Mol. Struct, 1028 (2012) 134-140.

[23] T. Umecky, K. Suga, E. Masaki, T. Takamuku, T. Makino, M. Kanakubo, Solvation structure and dynamics of $\mathrm{Li}+$ in Lewis-basic ionic liquid of 1-octyl-4-aza-1-azoniabicyclo [2.2. 2] octane bis (trifluoromethanesulfonyl) amide. J. Mol. Liq, 209 (2015) 557-562.

[24] J. Kausteklis, V. Aleksa, M.A. Iramain, S.A. Brandán, Cation-anion interactions in 1buthyl-3-methyl imidazolium nitrate ionic liquid and their effect on their structural and vibrational properties. J. Mol. Struct, 1164 (2018) 1-14.

[25] J. Kausteklis, V. Aleksa, M.A. Iramain, S.A. Brandán, DFT study and vibrational assignment of 1-Butyl-3-methylimidazolium trifluoromethanesulfonate ionic liquid by using the FT-Raman spectrum. J. Mol. Struct, 1175 (2019) 663-676.

[26] B Haddad, S A Brandán, A. M Amin, A Paolone, D Villemin, S. Bresson, Bidentate cation-anion coordination in the ionic liquid 1-ethyl-3-methylimidazolium hexafluorophosphate supported by vibrational spectra and NBO, AIM and SQMFF calculations, J. Mol. Struct. 128 (2020) 104-118.

[27] Mohammed Amin Assenine, Boumediene Haddad, Annalisa Paolone, Silvia Antonia Brandán, Didier Villemin, Mostefa Boumediene, Mustapha Rahmouni, Serge Bresson, Experimental and DFT studies on Structure, spectroscopic and thermal properties of NMethyl-N,N,N-trioctylammonium chloride ionic liquid. J. Mol. Struct, 5(17) (2020) 129625. 
[28] M.A. Assenine, B. Haddad, A. Paolone, S.A. Brandán, D. Villemin, M. Boumediene, M. Rahmouni, S. Bresson, Synthesis, thermal properties, vibrational spectra and computational studies of Trioctylmethylammonium bis (trifluoromethylsulfonyl) imide ionic liquid. Submitted to J. Mol. Struct. (2020).

[29] P. Pulay, G. Fogarasi, G. Pongor, J.E. Boggs, A. Vargha, Combination of theoretical ab initio and experimental information to obtain reliable harmonic force constants. Scaled quantum mechanical (QM) force fields for glyoxal, acrolein, butadiene, formaldehyde, and ethylene. J. Am. Chem. Soc, 105 (1983) 7037-7047.

[30] G. Rauhut, P. Pulay, Transferable Scaling Factors for Density Functional Derived Vibrational Force Fields. J. Phys. Chem., 99 (1995) 3093-3100.

[31] T. Sundius, Scaling of ab-initio force fields by MOLVIB. Vib. Spectrosc., 29 (2002) 8995.

[32] A.D. Becke, Density-functional exchange-energy approximation with correct asymptotic behavior. Phys. Rev., A38 (1988) 3098-3100.

[33] C. Lee, W. Yang, R.G. Parr, Development of the Colle-Salvetti correlation-energy formula into a functional of the electron density. Phys. Rev., B37 (1988) 785-789.

[34] S. Weber, J. Brünig, V. Zeindlhofer, C. Schröder, B. Stöger, A. Limbeck, ... ., K. Bica, Selective Hydrogenation of Aldehydes Using a Well-Defined Fe (II) PNP Pincer Complex in Biphasic Medium. ChemCatChem, 10(19) (2018) 4386-4394.

[35] A.B. Nielsen, A.J. Holder, GaussView, User's Reference, GAUSSIAN, Inc.: Pittsburgh, PA, USA, 2000-2003.

[36] Gaussian 09, Revision A.02, M. J. Frisch, G. W. Trucks, H. B. Schlegel, G. E. Scuseria, M. A. Robb, J. R. Cheeseman, G. Scalmani, V. Barone, B. Mennucci, G. A. Petersson, H. Nakatsuji, M. Caricato, X. Li, H. P. Hratchian, A. F. Izmaylov, J. Bloino, G. Zheng, J. L. Sonnenberg, M. Hada, M. Ehara, K. Toyota, R. Fukuda, J. Hasegawa, M. Ishida, T. Nakajima, Y. Honda, O. Kitao, H. Nakai, T. Vreven, J. A. Montgomery, Jr., J. E. Peralta, F. Ogliaro, M. Bearpark, J. J. Heyd, E. Brothers, K. N. Kudin, V. N. Staroverov, R. Kobayashi, J. Normand, K. Raghavachari, A. Rendell, J. C. Burant, S. S. Iyengar, J. Tomasi, M. Cossi, N. Rega, J. M. Millam, M. Klene, J. E. Knox, J. B. Cross, V. Bakken, C. Adamo, J. Jaramillo, R. Gomperts, R. E. Stratmann, O. Yazyev, A. J. Austin, R. Cammi, C. Pomelli, J. W. Ochterski, R. L. Martin, K. Morokuma, V. G. Zakrzewski, G. A. Voth, P. Salvador, J. J. Dannenberg, S. Dapprich, A. D. Daniels, Ö. Farkas, J. B. Foresman, J. V. Ortiz, J. Cioslowski, and D. J. Fox, Gaussian, Inc., Wallingford CT, 2009.

[37] E.D. Glendening, J.K. Badenhoop, A. D. Reed, J. E. Carpenter, F. Weinhold, NBO 3.1; Theoretical Chemistry Institute, University of Wisconsin; Madison, WI, 1996.

[38] R.F.W. Bader, Atoms in Molecules, A Quantum Theory, Oxford University Press, Oxford, 1990, ISBN: 0198558651.

[39] F. Biegler-Köning, J. Schönbohm, D. Bayles. AIM2000; A Program to Analyze and Visualize Atoms in Molecules. J. Comput. Chem., 22 (2001) 545.

[40] B.H. Besler, K.M. Merz Jr, P.A. Kollman, Atomic charges derived from semiempirical methods, J. Comp. Chem., 11 (1990) 431-439.

[41] G. Keresztury, S. Holly, G. Besenyei, J. Varga, A.Y. Wang, J.R. Durig. Vibrational spectra of monothiocarbamates -II. IR and Raman spectra, vibrational assignment, 
conformational analysis and ab initio calculations of S-methyl-N,N-dimethylthiocarbamate. Spectrochim. Acta., 49A (1993) 2007-2026.

[42] D. Michalska, R. Wysokinski, The prediction of Raman spectra of platinum (II) anticancer drugs by density functional theory. Chem. Phys. Lett., 403 (2005) 211-217.

[43] R. Ditchfield, Self-consistent perturbation theory of diamagnetism. I. A gage-invariant LCAO (linear combination of atomic orbitals) method for NMR chemical shifts. Mol. Phys. 27 (1974) 714-722.

[44] P. Ugliengo, MOLDRAW Program, University of Torino, Dipartimento Chimica IFM, Torino, Italy, 1998. 